\title{
Altered GABA Signaling in Early Life Epilepsies
}

\author{
Stephen W. Briggs and Aristea S. Galanopoulou \\ Saul R. Korey Department of Neurology, Dominick P. Purpura Department of Neuroscience, Albert Einstein College of Medicine, \\ 1410 Pelham Parkway South, Kennedy Center Rm 306, Bronx, NY 10461, USA
}

Correspondence should be addressed to Aristea S. Galanopoulou, aristea.galanopoulou@einstein.yu.edu

Received 7 February 2011; Revised 4 May 2011; Accepted 27 May 2011

Academic Editor: Laura Cancedda

Copyright ( $) 2011$ S. W. Briggs and A. S. Galanopoulou. This is an open access article distributed under the Creative Commons Attribution License, which permits unrestricted use, distribution, and reproduction in any medium, provided the original work is properly cited.

\begin{abstract}
The incidence of seizures is particularly high in the early ages of life. The immaturity of inhibitory systems, such as GABA, during normal brain development and its further dysregulation under pathological conditions that predispose to seizures have been speculated to play a major role in facilitating seizures. Seizures can further impair or disrupt $\mathrm{GABA}_{\mathrm{A}}$ signaling by reshuffling the subunit composition of its receptors or causing aberrant reappearance of depolarizing or hyperpolarizing $G_{A B A}{ }_{A}$ receptor currents. Such effects may not result in epileptogenesis as frequently as they do in adults. Given the central role of $\mathrm{GABA}_{\mathrm{A}}$ signaling in brain function and development, perturbation of its physiological role may interfere with neuronal morphology, differentiation, and connectivity, manifesting as cognitive or neurodevelopmental deficits. The current GABAergic antiepileptic drugs, while often effective for adults, are not always capable of stopping seizures and preventing their sequelae in neonates. Recent studies have explored the therapeutic potential of chloride cotransporter inhibitors, such as bumetanide, as adjunctive therapies of neonatal seizures. However, more needs to be known so as to develop therapies capable of stopping seizures while preserving the age- and sex-appropriate development of the brain.
\end{abstract}

\section{Introduction}

Epilepsy is a disease of recurrent seizures: that is, unprovoked episodes of aberrant synchronous excitation of brain regions that disrupt normal functioning $[1,2]$. Epileptic seizures are thought to reflect a failure in the ability to maintain the balance between excitation and inhibition. The mechanisms underlying seizures are complex and not uniform across the numerous seizure types that exist [1]. Furthermore, our ability to study these mechanisms is often limited by the tools we can use: we can only see as far and as much as those tools allow. Consequently, many of the hypotheses describing the pathogenesis of seizures are biased by the dominant ictal phenomena, unbalanced excitation-inhibition and aberrant neuronal synchronization, which may not necessarily be the actual ictogenic mechanisms. Neurotransmitters involved in neuronal inhibition, such as GABA, have attracted the major focus of research aiming to decipher mechanisms involved in ictogenesis. Under certain conditions, and definitely not in the majority of cases, seizures may lead to epilepsy or neurodevelopmental deficits. The early periods of life, when brain development is still incomplete, susceptibility to seizures is increased $[3,4]$. However, a combination of biological factors (genetic, age-related processes, epigenetic or environmental factors) protect neurons from seizureinduced injury, epileptogenesis, or mortality to a greater extent than the adult brain is protected [5]. It is increasingly recognized that seizures may leave their imprint on the developing brain by altering the way that neurons differentiate, connect, and communicate to each other, even if, in many cases, such changes may be ultimately compensated for. As extensively outlined in the reviews included within this special issue, GABA plays a central role in controlling neuronal development and communications. A major focus of research has therefore been thrown into efforts to elucidate its role not only in ictogenesis but also in the pathogenesis of the sequelae of early life seizures, whether this may be epilepsy, cognitive, or behavioral deficits [6].

There are three types of GABA receptors reported in the literature: $G_{A B A}, G A B A_{B}$, and $G A B A_{C}$, the latter classified more recently along with $G_{A B A}$ receptors, due to their functional similarities. Both $\mathrm{GABA}_{\mathrm{A}}$ and $\mathrm{GABA}_{\mathrm{C}}$ receptors 
are ligand-gated ionotropic channels that allow primarily chloride but also bicarbonate to cross their pore in response to GABA binding. $G_{A B A}$ is a metabotropic receptor that signals through cascades that modify potassium and calcium current (reviewed in [7]), direct migration [8], and control gene transcription $[9,10]$. In this review, we will focus primarily on $\mathrm{GABA}_{\mathrm{A}}$ receptors.

$\mathrm{GABA}_{\mathrm{A}}$ receptors are pentameric channels usually comprised of $2 \alpha$ and $2 \beta$ subunits, whereas the fifth is either a $\gamma$ or a $\delta$ subunit. Less frequently, $\varepsilon, \theta$, or $\pi$ subunits are present [11-13]. There are 16 known mammalian $\mathrm{GABA}_{\mathrm{A}}$ receptor subunits $(\alpha 1-\alpha 6, \beta 1-\beta 3, \gamma 1-\gamma 3, \delta, \varepsilon, \theta, \pi)$, which contribute towards the different pharmacokinetic, subcellular localization or affinity properties of each $\mathrm{GABA}_{\mathrm{A}}$ receptor complex. The presence of a $\rho$ subunit defines the $G_{A B A}$ receptors. Unlike $G_{A B A}$ receptors, $G_{A B A}$ are insensitive to bicuculline. The expression of $\mathrm{GABA}_{\mathrm{A}}$ receptor subunits changes with development and as a result the responsiveness of immature and adult neurons to $\mathrm{GABA}_{\mathrm{A}}$ ergic modulators are significantly different.

The classical inhibitory $\mathrm{GABA}_{\mathrm{A}}$ signaling, as occurs in most adult neurons, is due to chloride influx through the channel pore, which hyperpolarizes the cells. This is achieved because the intracellular chloride concentration is maintained at a low level, allowing chloride to flow in along its electrochemical gradient, when $\mathrm{GABA}_{\mathrm{A}}$ receptors open (Figure 1). Multiple studies over the last few decades have confirmed that this electrochemical chloride gradient is developmentally regulated by changes in the expression of cation-chloride cotransporters (CCCs). CCCs are the electroneutral ion symporters that establish the chloride gradient between cells and their extracellular environment. There are 3 CCC classes. The chloride importing CCCs are either the sodium/potassium/chloride cotransporters (NKCCs), with known representatives the NKCC1 and NKCC2, or the sodium chloride cotransporters (NCCs). Chloride exporters are the potassium/chloride cotransporters (KCCs), with 4 known isoforms: KCC1-4 (reviewed in $[11,12,14$, 15]) (Figure 1). Immature neurons express predominantly chloride-importers, such as NKCC1 [16], which generate high intracellular $\mathrm{Cl}^{-}$levels. This forces the open $\mathrm{GABA}_{\mathrm{A}}$ receptors to permit $\mathrm{Cl}^{-}$efflux through their channel pore, giving rise to depolarizing $\mathrm{GABA}_{\mathrm{A}}$ responses [16-18]. During developmental maturation, the expression of chlorideextruding CCCs, like the potassium/chloride cotransporter 2 (KCC2), dominates over NKCCs [19-22], decreasing the intracellular chloride concentration [23]. As a result, when GABA opens $\mathrm{GABA}_{\mathrm{A}}$ receptors the ensuing influx of chloride results in hyperpolarizing currents [19] (Figure 1). However, cell type, sex, and species/strain differences occur in the timing of this developmental shift. KCC1, KCC3 and KCC4 are widely expressed, but KCC2 is specific to neurons. This makes KCC2 particularly interesting for the pathogenesis and therapy of neural diseases. NKCC2 expression is specific to the kidney, leaving NKCC1 as the most relevant chloride-importing cotransporter for the brain, though it is expressed ubiquitously. Bicarbonate, generated by carbonic anhydrase, is another negatively charged ion that can permeate the $\mathrm{GABA}_{\mathrm{A}}$ receptor, generating a depolarizing response [12, 24, 25]. The cytosolic carbonic anhydrase VII (CAVII) increases around postnatal day 12 (PN12) in the rat hippocampus [26], rendering bicarbonate-mediated $\mathrm{GABA}_{\mathrm{A}}$ depolarizations more prominent [25].

There is considerable evidence that alterations in GABA signaling can cause seizures, as well as that seizures can change GABAergic signaling. In this review, we will discuss the bidirectional relationship of seizures to $\mathrm{GABA}_{\mathrm{A}}$ signaling at the level of the neurons, $\mathrm{GABA}_{\mathrm{A}}$ receptors, and the ionic symporters that control chloride homeostasis and the efficiency of $\mathrm{GABA}_{\mathrm{A}}$ receptor mediated inhibition.

\section{Correspondence of Developmental Stages between Rodents and Humans}

To facilitate the translation of the experimental data into humans, it is worth reminding that the accepted correspondence of developmental stages between rodents and humans considers that the first week of life in rodents is equivalent to a premature newborn human, whereas the time of birth in rodents is considered to correspond to PN8-10. The rodent infantile stage is thought to extend till PN21, the onset of puberty is at PN32-35 in rodents, whereas PN60 rodents are considered young adults. However, it is important to emphasize that this is a very oversimplified translation, based mostly on correspondence of protein and DNA content in the brain. Each developmental process occurs at different tempos and is not always in synchrony with the above sequence of events. For example, by the end of the first postnatal week, rats are able to walk away from the nest, quite unlike the human newborns who cannot yet ambulate [27]. Direct demonstration of the time of shift of $\mathrm{GABA}_{\mathrm{A}}$ receptor responses to hyperpolarizing has not been demonstrated in humans, though it has been suggested to occur before or soon after birth, based on the developmental patterns of the relative expression of NKCC1 and KCC2 [21, 28].

\section{The Immaturity of $\mathrm{GABA}_{\mathrm{A}}$ ergic Systems as an Age and Sex-Specific Risk Factor for Early Life Seizures}

Seizures are more common in the early periods of life and especially in males [3,4]. The immaturity of GABAergic inhibitory systems has been implicated in the heightened susceptibility of neonates to seizures and may also underlie the increased vulnerability of males, in whom the maturation of these systems is delayed compared to females. GABA is depolarizing in the neonatal life and it stays depolarizing for longer developmental periods in the male brain than in females [17, 29-33]. Paradoxical exacerbation of seizures by GABA-acting drugs has been reported in newborns, especially in low weight premature babies [34]. GABA-acting drugs, such as benzodiazepines and barbiturates, however, still remain the mainstay of treatments for neonatal seizures, even if they may not always be as effective in newborn human babies as in older patients [21,35-39]. This is thought to be due to shunting inhibition or inhibition via excitatory effects upon inhibitory interneurons [40]. The composition 


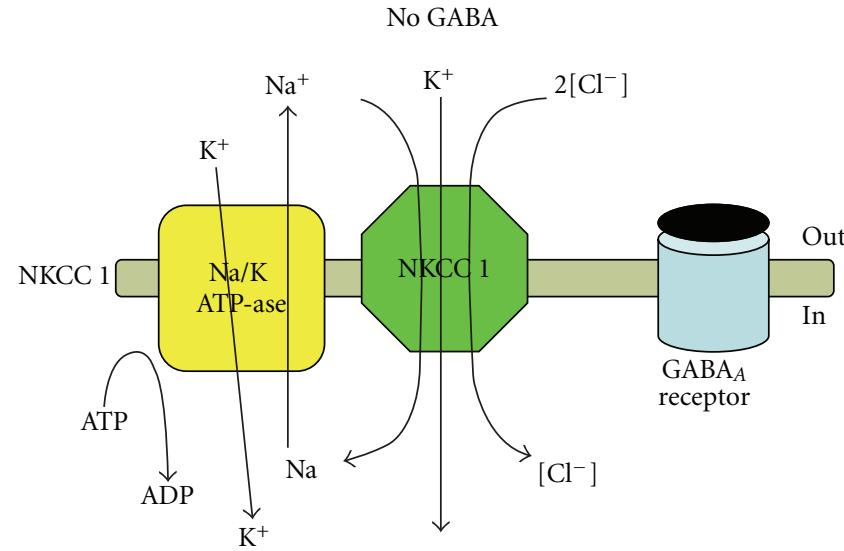

(a)

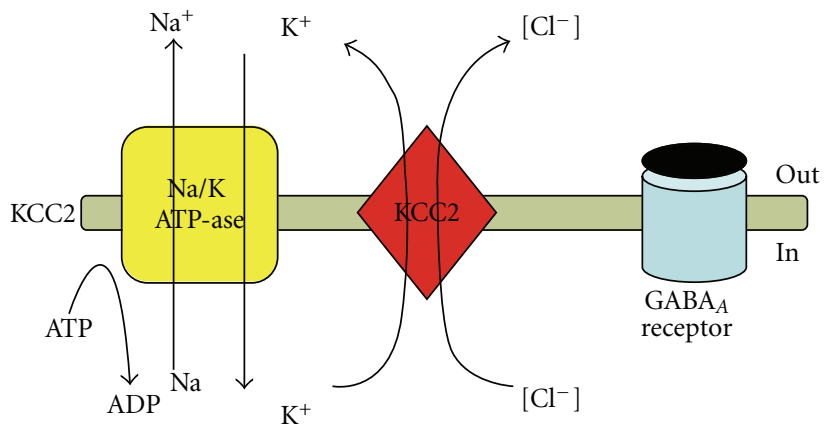

(c)

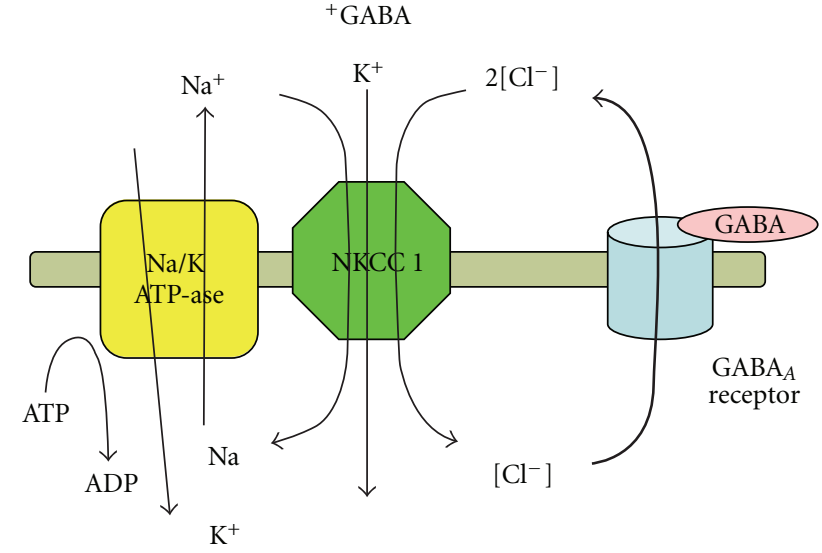

(b)

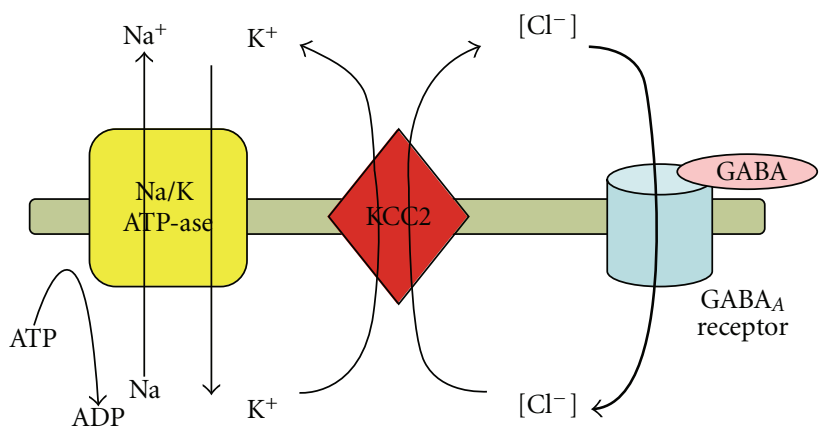

(d)

FIGURE 1: CCCs control GABA receptor-mediated inhibition. Panels (a) and (b) show the effects of NKCC1 activity in the absence (panel (a)) or presence (panel (b)) of GABA. NKCC1 mediates the electroneutral cotransport of $\mathrm{Na}^{+}, \mathrm{K}^{+}$, and $2 \mathrm{Cl}-$, increasing the intracellular $\mathrm{Cl}^{-}$concentration. As a result, upon binding of GABA upon the $\mathrm{GABA}_{\mathrm{A}}$ receptor, the channel pore opens and $\mathrm{Cl}$ leaves the neuron, causing a depolarization. Panels $\mathrm{c}$ and $\mathrm{d}$ show the effects of NKCC1 activity on $\mathrm{GABA}_{\mathrm{A}}$ receptor function in the absence (panel c) or presence (panel d) of GABA. KCC2 in contrast exports $\mathrm{K}^{+}$and $\mathrm{Cl}^{-}$reducing intracellular $\mathrm{Cl}^{-}$. Activation of $\mathrm{GABA}_{\mathrm{A}}$ receptors therefore results into influx of $\mathrm{Cl}$ and hyperpolarizing current. Their function is dependent upon the gradients of $\mathrm{Na}^{+}$and $\mathrm{K}^{+}$, which are controlled by various factors, including background conductances, membrane voltage, and by the $\mathrm{Na}^{+} / \mathrm{K}^{+}$ATPase.

of $\mathrm{GABA}_{\mathrm{A}}$ receptors is also different in newborns, with less $\alpha 1$ and more $\alpha 2 / 3$ subunits, rendering them less responsive to benzodiazepines $[41,42]$. Furthermore, the subcortical GABAergic networks that control seizures, like the substantia nigra pars reticulata (SNR), have not fully developed [31, 4246]. The excessive GABAergic stimulation of the SNR, as is thought to occur due to GABA release during seizures, has proconvulsant effects early in life and anticonvulsant in older animals and this switch occurs earlier in females [44, 45]. It is therefore important to investigate and clarify the exact molecular determinants that control $\mathrm{GABA}_{\mathrm{A}}$ inhibition in the young brain so as to optimize the treatment of seizures.

\section{Aberrant GABA Signaling Predisposes to Seizures}

Clinical and experimental evidences indicate that an initial perturbation of $\mathrm{GABA}_{\mathrm{A}}$ signaling may facilitate seizures. A loss of inhibition could result in runaway excitatory circuits. Too much inhibition could also cause a seizure, either by disinhibiting epileptogenic networks or via promoting neuronal synchronization ([67] reviewed by [68]). Excessive inhibition has been implicated in autosomal dominant nocturnal frontal lobe epilepsy (ADNFLE) ( [69] reviewed in [70]) or absence seizures [71]. Moreover, as $\mathrm{GABA}_{\mathrm{A}}$ signaling is critical for brain development and early synaptogenesis [72-74], a disorder of $\mathrm{GABA}_{\mathrm{A}}$ signaling early in life may cause miswiring or malformations that predispose to seizures (Figure 2).

Many GABA-related mutations are known to cause early life epilepsy. These include loss of function mutations or deletions of $\mathrm{GABA}_{\mathrm{A}}$ receptor subunit genes that reduce their expression, or the duration, amplitude or agonist sensitivity of $\mathrm{GABA}_{\mathrm{A}}$ currents. $\mathrm{GABA}_{\mathrm{A}}$ receptor subunit mutations have been implicated in childhood absence epilepsy (CAE) [50, 51, 75], autosomal dominant epilepsy with febrile seizures plus $\left(\mathrm{ADEFS}^{+}\right)$[76], and other epileptic syndromes (reviewed in Table 1 and $[77,78]$ ). Conditional mutants indicate that the developmental period of exposure to insults that disrupt $\mathrm{GABA}_{\mathrm{A}}$ signaling may be critical in ictogenesis and epileptogenesis. Chiu et al. proposed that loss of function mutations of the $\mathrm{GABA}_{\mathrm{A}}$ receptor subunits may have 
TABLE 1: GABA-related mutations linked with seizures.

\begin{tabular}{|c|c|c|c|c|}
\hline GABA-related mutations & Species & Epilepsy type & $\begin{array}{l}\text { Age at first } \\
\text { observation }\end{array}$ & Ref. \\
\hline \multicolumn{5}{|c|}{$\mathrm{GABA}_{\mathrm{A}}$ receptor mutations } \\
\hline GABRA1 & Human & ADJME, CAE & $\begin{array}{l}\text { Childhood, } \\
\text { Juvenile }\end{array}$ & $\begin{array}{l}{[47,} \\
48]\end{array}$ \\
\hline GABRA6 & Human & CAE & Childhood & [49] \\
\hline GABRB3 & Human & CAE & Childhood & $\begin{array}{r}{[50-} \\
52]\end{array}$ \\
\hline GABRD & Human & ADJME & Juvenile & [53] \\
\hline GABRE & Human & Febrile, $\mathrm{ADEFS}^{+} \mathrm{IGE}$ & $\begin{array}{l}\text { Infantile, } \\
\text { childhood }\end{array}$ & {$[49]$} \\
\hline GABRG2 & $\begin{array}{l}\text { Human, } \\
\text { mouse }\end{array}$ & $\begin{array}{l}\mathrm{CAE}^{+} \text {Febrile, } \\
\mathrm{ADEFS}^{+}, \text {SMEI } \\
\text { ADEFS }^{+}, \text {SMEI, } \\
\text { Febrile }\end{array}$ & $\begin{array}{l}\text { Infantile, } \\
\text { childhood }\end{array}$ & $\begin{array}{c}{[54-} \\
59]\end{array}$ \\
\hline GABRP & Human & IGE, $\mathrm{ADEFS}^{+}$, Febrile & $?$ & [49] \\
\hline \multicolumn{5}{|c|}{ Other mutations } \\
\hline GAD65 knockout & Mouse & $\begin{array}{l}\text { Stress-induced, } \\
\text { Limbic seizures }\end{array}$ & 12 weeks & $\begin{array}{l}{[60,} \\
61]\end{array}$ \\
\hline ARX mutations & $\begin{array}{l}\text { Human, } \\
\text { mice }\end{array}$ & $\begin{array}{l}\text { Early life epileptic } \\
\text { encephalopathies } \\
\text { (infantile spasms, } \\
\text { Ohtahara) }\end{array}$ & $\begin{array}{l}\text { Neonatal, } \\
\text { Infantile }\end{array}$ & $\begin{array}{r}{[62-} \\
66]\end{array}$ \\
\hline
\end{tabular}

developmental effects in addition to their direct electrophysiological consequences [79]. Using a conditionally expressed loss of function mutation of the $\gamma 2 \mathrm{GABA}_{\mathrm{A}}$ receptor subunit in mice, the investigators expressed the mutant allele for different periods of time. Mice that were induced to express the mutant allele for longer developmental periods displayed higher seizure susceptibility to pentylenetetrazole (PTZ), a drug that acts as a $\mathrm{GABA}_{\mathrm{A}}$ receptor antagonist, compared to mice with late disruption of the $\gamma 2$ subunit expression.

Glutamic acid decarboxylase (GAD) isoforms GAD65 and GAD67 synthesize GABA in the brain. Knockout mice for the pyridoxal-5'-phosphate inducible GAD65 isoform, that generates the GABA reserve pools, have lower seizure threshold to picrotoxin, a $G_{A B A}$ receptor antagonist [61], or spontaneous seizures that can be precipitated by stress [60]. Although total GABA content in the brain may be normal or decreased in GAD65 knockout mice, depending upon the genetic substrate, it has been proposed that GAD65 loss of function may preferentially decrease the presynaptic reserve pool of GABA and decrease the tonic GABA inhibition, leading to increased seizure susceptibility [80-82]. Although no human GAD mutations have been found to consistently cause epilepsy [83], mutations in co-factors that are necessary for GAD65 function have been linked with early life seizures, as occurs in pyridoxine-de-pendency disorders $[84,85]$. GAD65 or GAD67 loss suf-ficiently compensates for each other and does not appear to affect early brain development; albeit, cleft palate has been reported with GAD67 knockout mice [86]. Dual GAD65/67 knockout mice are not viable [87]. A small subset of patients manifests epilepsy secondary to an autoimmune response against
GAD65/67, although these appear mostly in adults [8891].

\section{Disrupting CCC Function May Predispose to Seizures}

Decreased expression or function of chloride extruders may change seizure susceptibility by not only diminishing the efficacy of $\mathrm{GABA}_{\mathrm{A}}$ inhibition and promoting cellular swelling and degeneration under hypotonic conditions, but also by exerting broader developmental effects. Human linkage studies or transgenic knockout animal studies document that, at least in certain cases, seizures and epilepsy may ensue. There is currently no known human mutation of KCC2 associated with epilepsy. This may rather reflect the indispensability of $\mathrm{KCC} 2$, as complete $\mathrm{KCC} 2$ knockout mice die postnatally from respiratory failure, due to the immaturity of the respiratory system [93]. KCC2 has two known isoforms, KCC2a and KCC2b, of which KCC2b is thought to contribute to the developmental shift to hyperpolarizing $\mathrm{GABA}_{\mathrm{A}}$ receptor currents [106]. KCC2bknockout mice demonstrate hyperexcitability at PN10 to PN16 (equivalent to human infantile age) [94] (Table 2). Although the expected intracellular accumulation of chloride and depolarizing shift of $\mathrm{GABA}_{\mathrm{A}}$ responses could easily explain the hyperexcitability, application of the $\mathrm{GABA}_{\mathrm{A}}$ receptor antagonist picrotoxin paradoxically retains its excitatory responses [94]. Similarly, a different hypomorphic mutation in KCC2 causes a lower PTZ threshold for induction of clonic seizures in mice, despite the absence of gross morphological changes [95]. Such observations are 
TABle 2: Phenotype of CCC mutations.

\begin{tabular}{|c|c|c|c|c|c|}
\hline CCC & Location & Mutation & Species & $\begin{array}{l}\text { Neurological } \\
\text { effect }\end{array}$ & Ref. \\
\hline $\mathrm{KCC} 1$ & Ubiquitous & Knockout & Mouse & None seen & {$[92]$} \\
\hline \multirow[t]{4}{*}{ KCC2 } & Brain & $\begin{array}{l}\text { KCC2a and } \\
\text { KCC2b } \\
\text { knockout }\end{array}$ & Mouse & Death at birth & {$[93]$} \\
\hline & Brain & $\begin{array}{l}\text { KCC2b } \\
\text { knockout }\end{array}$ & Mouse & $\begin{array}{l}\text { Seizures, low } \\
\text { weight, early } \\
\text { mortality }\end{array}$ & {$[94]$} \\
\hline & Brain & Hypomorph & Mouse & $\begin{array}{l}\text { Increased seizure } \\
\text { susceptibility and } \\
\text { anxiety }\end{array}$ & {$[95]$} \\
\hline & Brain & Heterozygote & Mouse & Hyperexcitability & {$[96]$} \\
\hline KCC3 & Ubiquitous & $\begin{array}{l}\text { KCC3a-c } \\
\text { knockout }\end{array}$ & $\begin{array}{l}\text { Human, } \\
\text { mouse }\end{array}$ & $\begin{array}{l}\text { Peripheral } \\
\text { neuropathy; } \\
\text { seizures have } \\
\text { been reported }\end{array}$ & $\begin{array}{l}{[97-} \\
100]\end{array}$ \\
\hline $\mathrm{KCC} 4$ & Kidney, heart, lungs, liver & Knockout & Mouse & Deafness & {$[101]$} \\
\hline \multirow[t]{2}{*}{ NKCC1 } & Ubiquitous & $\begin{array}{l}\text { NKCC1a } \\
\text { knockout }\end{array}$ & Mouse & $\begin{array}{l}\text { Deafness, circling } \\
\text { behavior }\end{array}$ & {$[102]$} \\
\hline & Ubiquitous & $\begin{array}{l}\text { NKCC1a and } \\
\text { NKCC1b } \\
\text { knockout }\end{array}$ & Mouse & $\begin{array}{l}\text { Deafness, circling } \\
\text { behavior, growth } \\
\text { retardation, } \\
\text { defective } \\
\text { spermatogenesis, } \\
\text { increased } \\
\text { threshold to } \\
\text { thermal } \\
\text { stimulation }\end{array}$ & $\begin{array}{l}{[103,} \\
104]\end{array}$ \\
\hline NKCC2 & Kidney & Knockout & Human & $\begin{array}{l}\text { Bartter's } \\
\text { syndrome }\end{array}$ & {$[105]$} \\
\hline
\end{tabular}

indicative of a residual inhibitory capacity of KCC2, either in the form of less potent hyperpolarizing $\mathrm{GABA}_{\mathrm{A}}$ receptor currents or shunting inhibition [107]. However, the function of KCC2 is more complex, due to interactions with dendritic cytoskeletal proteins [108] or with other modulators of neuronal activity (i.e., increasing extracellular potassium) [109] which need to be further analyzed as to their ability to influence the phenotype of these mice.

Loss of function mutations in KCC3, which is expressed in many tissues, have been reported in patients with hereditary motor sensory neuropathy, some of whom have seizures as well as developmental deficits, like agenesis of the corpus callosum [100].

Altered CCCs may also affect brain development in a more subtle fashion, which could predispose a brain to epilepsy even if it does not directly cause seizures. From various fronts evidence emerges that shifts in the timing of emergence of hyperpolarizing signaling may have significant impact on neuronal and brain development and connectivity. Precocious appearance of hyperpolarizing $\mathrm{GABA}_{\mathrm{A}}$ receptor signaling, either by KCC2 overexpression [72] or via loss of NKCC1 activity [110], disrupts cortical morphogenesis. Pharmacological inhibition of NKCC1 with bumetanide from embryonic day E15 to PN7 in otherwise normal mice disrupts cortical dendritic formation [74]. Abnormal cortical development and synaptic connectivity may predispose to seizures or cognitive impairment, which is both a predisposing factor and a common comorbidity of young patients with epilepsy [111].

\section{Secondary Disruption of GABAergic Signaling in Risk Factors for Early Life Epilepsy}

Conditions that predispose to epilepsy, genetic or acquired, may also create an imbalance in excitation/inhibition. Although their effects are not restricted to $\mathrm{GABA}_{\mathrm{A}}$ signaling, in certain cases they may show a predilection to preferentially impair GABAergic inhibition.

Mutations of the aristaless-related and X-linked homeobox gene ARX have attracted a lot of interest due to their linkage with early life catastrophic epileptic syndromes, such as infantile spasms, Ohtahara syndrome, X-linked myoclonic seizures, spasticity and intellectual disability, idiopathic infantile epileptic dyskinetic encephalopathy, X-linked mental retardation [63-66, 112-116] (reviewed in [117]). ARX is a transcription factor that regulates the proliferation and 


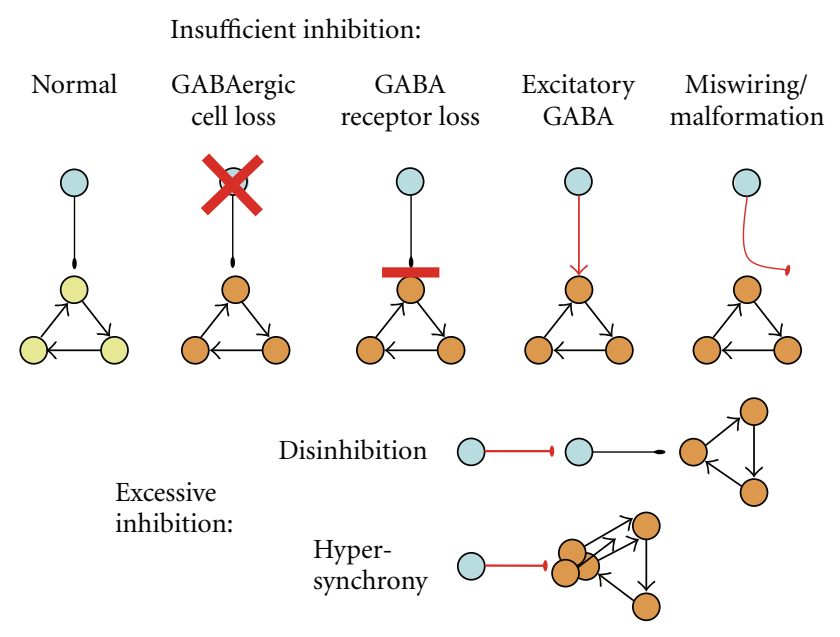

FIgURE 2: Schematic depiction of simple models through which dysregulation of $\mathrm{GABA}_{\mathrm{A}}$ receptor-mediated inhibition can increase the activity of neuronal networks, potentially generating seizures. GABA inhibition can fail when GABA or $\mathrm{GABA}_{\mathrm{A}}$ receptor expression is low, when GABA depolarizes neurons, or when miswiring and mistargeting of synapses occur. Excessive GABA inhibition may trigger seizures by disinhibiting target cells, or via excessive synchronization of the neurons in the epileptogenic focus. Please note that the effects of dysregulated GABA signaling in more complex neuronal networks, especially in the presence of abnormal circuitry or with specific pathologies, may differ. In such cases a combination of the above models may be applicable at different sites of the epileptogenic network rendering the pharmacological effect of a GABAergic agonist not completely predictable by a single model. Furthermore, shunting inhibition may explain situations where GABAergic drugs silence excessive excitatory network activity, in neurons with depolarizing GABAergic signaling.

migration of GABA, calbindin, or neuropeptide $\mathrm{Y}$ positive interneurons but also of striatal cholinergic neurons [64, 66, 117]. Two recently published mouse models of ARX loss of function mutations, one of which specifically disrupted it in GABAergic interneurons destined to migrate to the neocortex, have recapitulated several phenotypes of infantile spasms and associated phenotype (cognitive, behavioral deficits and epileptogenesis) emphasizing the importance of deficient GABA inhibition for their pathogenesis $[64,66]$.

Angelman syndrome, a rare chromosomal deletion, involves the loss of ubiquitin-protein ligase 3A (UBE3A), but in certain patients there is a more extensive deletion of the 15q11-13 chromosomal locus that contains three $\mathrm{GABA}_{\mathrm{A}}$ subunits, $\alpha 5, \beta 3$, and $\gamma 3 \mathrm{GABA}_{\mathrm{A}}$ receptor subunits [118]. Genotype-phenotype correlation suggested that deletion of the $\mathrm{GABA}_{\mathrm{A}}$ receptor subunits is associated with more severe seizures, including infantile spasms, atypical absences, and myoclonus whereas patients with UBE3A mutations had a milder phenotype [118]. The $\beta 3$ subunit knockout mouse strain also develops a similar epilepsy phenotype [119].

Loss of function mutations of the voltage-sensitive sodium channel SCN1A gene is found in not only the severe myoclonic epilepsy of infancy (Dravet syndrome) but also in $\mathrm{ADEFS}^{+}$syndrome [120-123]. SCN1A mutations have been proposed to preferentially impair the sodium channel activity of GABAergic interneurons, diminishing their activity [124]. Anti-NMDA autoantibodies detected in limbic encephalitis, a rare cause of refractory and frequent seizures [125], have been speculated to selectively target the NMDA receptors of presynaptic GABAergic terminals, reducing therefore GABA release [126].

Aberrant reappearance of depolarizing $\mathrm{E}_{\mathrm{GABA}}$ and reduced $\mathrm{GABA}_{\mathrm{A}}$ ergic responses have been proposed to underlie the pathogenesis of seizures from cortical malformations. Pathology and electrophysiological studies from human tissue specimens from patients with cortical dysplasias, that commonly predispose to early life seizures, have also suggested the presence of depolarizing GABA [20, 127, 128]. In the neonatal freeze lesion model, a shift to the immature pattern of high NKCC1/KCC2 ratio in the lesional site [129] as well as reduced $\gamma 2$ subunit expression and sensitivity to $\alpha 1$ subunit agonists in adulthood was described $[130,131]$. In the rat model of cortical dysplasias induced by prenatal exposure to the 1-3-bis-chloroethyl-nitrosurea, reduced sensitivity to GABA was also seen in adulthood [132].

Traumatic brain injury in adults, such as in axotomized neurons, causes a reversal of $\mathrm{GABA}_{\mathrm{A}}$ signaling and CCC expression profile to the immature pattern (more depolarizing GABA and dominant NKCC1 over KCC2 activity) [133-135]. This appears to aid the survival and regeneration process, promoting the brain-derived neurotrophic factor(BDNF-) dependent neuronal survival and may resolve with time, during recovery [135]. However, there is limited information as to the consequences of neuronal trauma upon the expression, physiology, and connectivity of GABAergic interneurons in developing animals. In the partially iso-

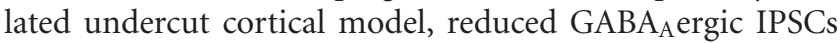
and impaired chloride extrusion were found in juvenile rats, suggesting a possible correlation between impaired GABAergic inhibition and posttraumatic cortical excitability $[136,137]$. Few studies have advocated against the use of GABA enhancing drugs and in favor of $\mathrm{GABA}_{\mathrm{A}}$ receptor inhibitors as interventions to improve cognitive outcomes [138]. More detailed studies are needed to determine the role of posttraumatic $\mathrm{GABA}_{\mathrm{A}}$ signaling changes for healing and regeneration in the developing brain as well as its impact on subsequent epileptogenesis and ensuing cognitive deficits.

\section{Seizures Alter GABA $\mathbf{A}_{\mathbf{A}}$ Signaling}

Seizures can affect almost every neurotransmitter system in the brain. Seizures can have immediate effects on $\mathrm{GABA}_{\mathrm{A}}$ signaling, that is, during the ictal period, or delayed, appearing after the termination of seizures. In both scenarios, the observed changes are dynamic and evolving. Seizures may interfere with the expression, composition, and subcellular distribution of $\mathrm{GABA}_{\mathrm{A}}$ receptors and their regulatory factors, such as CCCs or regulatory kinases. Defining the timing of these events is crucial, not only to better understand the pathophysiological mechanisms investigating these changes but also to best interpret their pathophysiological relevance for epileptogenesis and brain function. The temporal 
TABLE 3: Effects of early life seizures on $\mathrm{GABA}_{\mathrm{A}}$ receptors and currents in rats.

\begin{tabular}{|c|c|c|c|c|}
\hline Seizure model & Age & Region & $\begin{array}{l}\text { Effects on } \mathrm{GABA}_{\mathrm{A}} \\
\text { receptors }\end{array}$ & Ref. \\
\hline \multicolumn{5}{|c|}{ Ictal changes } \\
\hline $\begin{array}{l}\text { In vivo SE } \\
\text { (Lithium-pilocarpine; } \\
\text { continuous } \\
\text { hippocampal } \\
\text { stimulation) }\end{array}$ & PN30 & Hippocampus & $\begin{array}{l}\text { Reduced surface } \\
\text { expression of } \beta 2 / 3, \gamma 2 \\
\text { subunits but not of } \delta \text {. }\end{array}$ & [139] \\
\hline $\begin{array}{l}\text { In vivo SE } \\
\text { (lithium-pilocarpine) }\end{array}$ & $4-7$ week old & Hippocampus & $\begin{array}{l}\text { Internalization of } \beta 2 / 3 \text {, } \\
\gamma 2 \text { subunits; reduced } \\
\text { mIPSCs }\end{array}$ & [140] \\
\hline \multicolumn{5}{|c|}{ After seizures } \\
\hline $\begin{array}{l}\text { Recurrent flurothyl } \\
\text { seizures }\end{array}$ & PN1-5 & $\begin{array}{l}\text { Hippocampus, } \\
\text { somatosensory } \\
\text { cortex }\end{array}$ & $\begin{array}{l}\text { Decreased amplitude of } \\
\text { GABAergic IPSCs }\end{array}$ & $\begin{array}{l}{[141,} \\
142]\end{array}$ \\
\hline Flurothyl seizures & PN6 or PN6-10 & Hippocampus & $\begin{array}{l}\text { Decreased numbers of } \\
\alpha 1 \text {-ir neurons }\end{array}$ & [143] \\
\hline Kainic acid SE & PN9 & Hippocampus & $\begin{array}{l}\text { At } 3 \text { weeks postictally: } \\
\alpha 1, \\
\alpha 4, \gamma 2 \text { decrease; } \\
\alpha 2, \alpha 3 \text { increase; } \\
\alpha 5 \text { increase (CA3 only); } \\
\beta 3 \text { increase compared to } \\
\text { controls }\end{array}$ & [144] \\
\hline Lithium-pilocarpine & PN10 & $\begin{array}{l}\text { Hippocampus } \\
\text { (dentate gyrus) }\end{array}$ & $\begin{array}{l}\text { In adulthood: increased } \\
\alpha 1 \text { expression, larger } \\
\text { GABA current, } \\
\text { enhanced zolpidem } \\
\text { sensitivity }\end{array}$ & [145] \\
\hline $\begin{array}{l}\text { Lithium-pilocarpine } \\
\text { SE }\end{array}$ & PN20 & Hippocampus & $\begin{array}{l}\text { Decreased } \alpha 1 \text { and } \\
\text { increased } \alpha 4 \text { expression } \\
\text { in the hippocampus of } \\
\text { epileptic versus } \\
\text { non-epileptic rats }\end{array}$ & [146] \\
\hline
\end{tabular}

evolution of these events is also particularly important in developing rats, given the maturational changes that are ongoing. In addition, the age at first seizure, the type and severity of seizures, sex, epigenetic factors, medications, but also the cellular diversity of specific operant signaling systems further modify the final outcomes.

\subsection{Ictal Attenuation of $G A B A_{A}$ Receptor-Mediated Inhibition.} The urgency in treating early SE has long been recognized in the clinical literature. GABA-acting drugs, like benzodiazepines or barbiturates, are more effective early at onset of seizures than later on, when SE has been established $[147,148]$. The transience of the efficacy of GABAergic drugs has been attributed to either increase internalization of selective synaptic $\mathrm{GABA}_{\mathrm{A}}$ receptor subunits, such as of $\beta 2 / 3$ and $\gamma 2$, which mediate the effects of benzodiazepines and barbiturates $[139,140]$. On the other hand, extrasynaptically located subunits that mediate tonic GABA inhibition, like the $\delta$ subunit, are not affected [139]. Failure of $\mathrm{GABA}_{\mathrm{A}}$ receptor-mediated inhibition during prolonged seizures may also occur due to a positive shift in $\mathrm{E}_{\mathrm{GABA}}$ either because of buildup of intracellular $\mathrm{Cl}^{-}$concentration, from intense
$\mathrm{GABA}_{\mathrm{A}}$ receptor-mediated chloride inward pumping, or from impaired chloride extrusion mechanisms, due to increased NKCC1 activity or decreased KCC2-mediated $\mathrm{Cl}^{-}$ efflux [149-151].

7.2. Postictal Changes. Loss of GABAergic interneurons is a hallmark pathology of focal epilepsies, like mesial temporal sclerosis [152-157]. In experimental studies, prolonged seizures can lead to interneuronal loss but such effects are age-specific. In newborn rats, during the first week of life, even 3 episodes of status epilepticus (SE) do not injure GABAergic neurons [30]; yet cell death becomes a progressively more prominent feature as the age at exposure to SE increases [155, 158-160]. In contrast, early life seizures functionally disrupt the physiology of $\mathrm{GABA}_{\mathrm{A}}$ receptor system. Age at the time of seizures, etiology or model of seizures, biological factors such as sex, as well as cell type and region-specific features may determine the end effects upon $\mathrm{GABA}_{\mathrm{A}}$ receptor subunits or the direction of $\mathrm{GABA}_{\mathrm{A}}$ receptor-mediated responses (Tables 3 and 4). These changes may be either compensatory attempts to repair or restore normal function or, on the contrary, may contribute 
TABLE 4: Effects of Seizures on CCCs.

\begin{tabular}{|c|c|c|c|c|c|}
\hline Model & Species & $\begin{array}{c}\text { Age at } \\
\text { seizures }\end{array}$ & Region & Effects & Ref. \\
\hline \multicolumn{6}{|c|}{ Ictal changes } \\
\hline $\begin{array}{l}\text { Kainic } \\
\text { acid }\end{array}$ & Rat & PN6-7 & Hippocampus & $\begin{array}{l}\text { Switch from } \\
\text { hyperpolarizing } \\
\text { to depolarizing } \\
\mathrm{E}_{\mathrm{GABA}}\end{array}$ & [184] \\
\hline $\begin{array}{l}\text { Low } \\
\mathrm{Mg}^{2+} \\
\text { seizures }\end{array}$ & Mice & PN5 & Hippocampus & $\begin{array}{l}\text { Bumetanide } \\
\text { sensitive } \\
\text { increase in } \\
{\left[\mathrm{Cl}^{-}\right]_{\mathrm{i}}}\end{array}$ & [150] \\
\hline \multicolumn{6}{|c|}{ After seizures } \\
\hline $\begin{array}{l}\text { Kainic } \\
\text { acid }\end{array}$ & $\begin{array}{c}\text { Rat } \\
\text { (male) }\end{array}$ & PN4-6 & $\begin{array}{l}\text { Hippocampus } \\
\text { (at least } 4 \text { days } \\
\text { postictally) }\end{array}$ & $\begin{array}{l}\text { Increased KCC2; } \\
\text { decreased } \\
\text { NKCC1 activity; } \\
\text { more } \\
\text { hyperpolarizing } \\
\mathrm{E}_{\mathrm{GABA}}\end{array}$ & [185] \\
\hline $\begin{array}{l}\text { Kainic } \\
\text { acid }\end{array}$ & $\begin{array}{c}\text { Rat } \\
\text { (female) }\end{array}$ & PN4-6 & $\begin{array}{l}\text { Hippocampus } \\
\text { (at least } 4 \text { days } \\
\text { postictally) }\end{array}$ & $\begin{array}{l}\text { No change in } \\
\text { KCC2; increased } \\
\text { NKCC1 activity; } \\
\text { more } \\
\text { depolarizing } \\
\text { E }_{\text {GABA }}\end{array}$ & [185] \\
\hline $\begin{array}{l}\text { Kainic } \\
\text { acid }\end{array}$ & $\begin{array}{c}\text { Rat } \\
\text { (male) }\end{array}$ & PN5-7 & $\begin{array}{l}\text { Hippocampus } \\
\text { (immediate } \\
\text { postictal } \\
\text { period) }\end{array}$ & $\begin{array}{l}\text { Increased } \\
\text { surface } \\
\text { expression of } \\
\text { KCC2; } \\
\text { hyperpolarizing } \\
\text { shift of } E_{\mathrm{GABA}}\end{array}$ & [171] \\
\hline
\end{tabular}

to the postictal dysfunction, comorbidities, or sequelae of seizures, such as cognitive dysfunction or epileptogenesis. Unlike the adults, in which the physiology of $\mathrm{GABA}_{\mathrm{A}}$ receptor-mediated signaling has reached a relative steady state, developmental research is further complicated by the evolving changes that normally occur during the period when brain matures[161]. There is no systematic research study taking us step-by-step through all the complexity of seizure-induced postictal alterations in $\mathrm{GABA}_{\mathrm{A}}$ receptor physiology and any extrapolations should be cautiously done pending confirmation by actual experimentations.

Seizures selectively interfere with the expression of certain, but not all, $\mathrm{GABA}_{\mathrm{A}}$ receptor subunits [141-146] (Table 3). Kainic acid SE at PN9 rats favors the preservation of the immature pattern of $\mathrm{GABA}_{\mathrm{A}}$ receptor complex (less $\alpha 1$, more $\alpha 2 / \alpha 3$ subunits) on the third postictal week [144] that typically attributes slower IPSC kinetics and less sensitivity to benzodiazepines. Similarly, recurrent flurothylinduced seizures, in the first 10 days of life, decrease $\alpha 1$ expression and the amplitude of $\mathrm{GABA}_{\mathrm{A}}$ receptor-mediated IPSCs [141-143]. Looking at longer-term outcomes of early life seizures, during adulthood, Brooks-Kayal's group has demonstrated that age at onset of SE is key at defining the final composition of $\mathrm{GABA}_{\mathrm{A}}$ receptors and that this, in turn, may contribute to epileptogenesis. Lithium-pilocarpine SE at PN10 increases $\alpha 1$ subunit expression in the dentate granule cells in adulthood; in contrast, if SE is induced at PN20, a decrease in $\alpha 1$ subunit is noted, but only in the epileptic animals $[145,146]$. Interestingly, reconstitution of $\alpha 1$ subunit expression prevented the occurrence of spontaneous seizures $[146,162]$.

The reports of untimely appearance of depolarizing $\mathrm{GABA}_{\mathrm{A}}$ receptor signaling in a subpopulation of subicular neurons from adult human epileptic resected temporal lobes have attracted a lot of interest as a possible mechanism of epileptogenicity and potential refractoriness to GABA-acting antiepileptics $[163,164]$. Depolarizing $\mathrm{GABA}_{\mathrm{A}}$ receptor signaling has been linked to a dominance of NKCC1 over KCC2 activity in certain neurons of the epileptic tissue. It may also occur because of effective replenishment of intracellular bicarbonate by carbonic anhydrase during intense $\mathrm{GABA}_{\mathrm{A}}$ receptor activation, which leads to a depolarization and to a consequent influx of $\mathrm{Cl}^{-}$, that enhances KCC2mediated $\mathrm{K}^{+} / \mathrm{Cl}^{-}$efflux [109]. The sequential interaction between carbonic anhydrase/ $\mathrm{GABA}_{\mathrm{A}}$ receptors/KCC2 may therefore increase extracellular $\mathrm{K}^{+}$, a factor that promotes the generation of ictal events. In support, carbonic anhydrase inhibitors have been used in certain cases as anticonvulsant therapies [109, 165].

Seizures in adult animals tend to increase the ratio of NKCC1 over KCC2 activity, reverting to a more immature pattern of CCC balance that favors depolarizing $\mathrm{E}_{\mathrm{GABA}}[151$, 166]. This is believed to occur in humans as well [127, 167$170]$. But what happens, then, after early life seizures, when neurons are already in an immature state and how does this impact epileptogenesis and functional outcomes? In the immediate postictal period, following brief recurrent kainic acid seizures or an hour of kainic acid SE, KCC2 is reshuffled towards the plasma membrane, increasing its capacity to export $\mathrm{Cl}^{-}[171]$. As a result $\mathrm{E}_{\mathrm{GABA}}$ becomes more negative, contributing perhaps to the ability of the neurons to stop seizures.

In the longer run, further changes in $\mathrm{E}_{\mathrm{GABA}}$ function occur, which are attributed to altered CCC expression or activity [30]. In our lab, we were interested in determining whether the original $\mathrm{E}_{\mathrm{GABA}}$, at the time seizures occur, may control the effects of seizures on CCCs and the direction of $\mathrm{GABA}_{\mathrm{A}}$ receptor-mediated signaling, in other words, whether seizures might have different effects upon $G_{A B A}$ receptor-mediated signaling in neurons with depolarizing or hyperpolarizing $\mathrm{GABA}_{\mathrm{A}}$ receptor mediated responses at the time of seizures. Taking advantage from the earlier appearance of $\mathrm{GABA}_{\mathrm{A}}$ receptor currents in females than in males, we compared the effects of 3 episodes of kainic acid SE elicited at PN4, 5, and 6 (3KA-SE) in CA1 pyramidal neurons with depolarizing $\mathrm{E}_{\mathrm{GABA}}$ (i.e., male) or isoelectric/hyperpolarizing $\mathrm{E}_{\mathrm{GABA}}$ (i.e., female) at the time of seizures [30]. We found that 3KA-SE caused only a transient appearance of depolarizing $\mathrm{GABA}_{\mathrm{A}}$ receptor mediated responses in neurons that had already started to shift to mature and more hyperpolarizing $\mathrm{E}_{\mathrm{GABA}}$, similar to what was previously described for the adult neurons. In contrast, in male neurons, with still depolarizing GABAergic responses, 3KA-SE caused a precocious emergence of mature, hyperpolarizing responses. These changes were attributed to 
altered expression and/or activity of KCC2 and NKCC1. The precocious termination of depolarizing $\mathrm{GABA}_{\mathrm{A}}$ signaling would be expected to deprive brain from its neurotrophic effects that are important for normal development $[72,74]$. Indeed, 3KA-SE-exposed pups develop learning and memory problems when they grow up (unpublished data). However, the inability of the immature neurons to persistently exhibit depolarizing $\mathrm{GABA}_{\mathrm{A}}$ receptor-mediated responses after seizures could be a protective feature against the development of subsequent epilepsy [30]. Our results indicate that age-specific factors, including the depolarizing GABA, may be important for this protection. Another dual regulator of CCCs and $\mathrm{E}_{\mathrm{GABA}}$ through development is the brainderived neurotrophic factor (BDNF) pathway, which is also activated in certain seizure models. BDNF increases KCC2 in developing neurons but decreases it in mature neurons $[172,173]$. The opposite patterns of KCC2 regulation by BDNF in certain systems has been proposed to be due to trkB-mediated activation of different intracellular signaling cascades that regulate KCC2 expression [151].

The maturation of $\mathrm{GABA}_{\mathrm{A}}$ receptor system occurs asynchronously across different neuronal types and brain regions. As a result, since early life seizures change the direction and strength of $\mathrm{GABA}_{\mathrm{A}}$ receptor-mediated inhibition, their effects will be region and cell type specific, further confusing the interneuronal communication protocols. They may also disrupt the basic neural processes of learning and cognitive processing that depend upon GABA neurotransmission, such as long-term potentiation (LTP) [174-176], or social interactions [177-182]. The result will be a state of postictal confusion or more sustained cognitive or behavioral deficits [6]. Of interest, bumetanide treatment has shown benefit in five infants with autism [183]. However the exact mechanisms underlying this therapeutic effect are not yet known.

\section{Implications for Early Life Seizures and Their Treatment}

Human and experimental evidence indicates that similar to adults, aberrant preservation of depolarizing $\mathrm{GABA}_{\mathrm{A}}$ signaling may also be a feature of the medically refractory epileptogenic focus in early life epilepsies. At present we do not have any data to discuss the pathological features of the medically sensitive early life epilepsies. The idea of pharmacologically enhancing GABA inhibition to stop seizures by using NKCC1 inhibitors like bumetanide is under investigation as a rationally developed, smart intervention to overcome the barriers posed by the well-established molecular switch of $\mathrm{GABA}_{\mathrm{A}}$ receptor function [21]. Beneficial effects have been shown in few animal models [21, 186189] and a human case report [190]. However, model-specific differences, as well as the timing of administration, can influence its efficacy in suppressing seizures $[96,191]$. Moreover, concerns have been raised about potential adverse developmental effects on innocent bystander normal brain tissues, as may occur in chronic use in patients with focal epilepsies [74]. Undoubtedly, more studies need to be done to determine which seizure types are more likely to respond, when is the optimal time to administer, for how long, and how such interventions influence long-term outcomes in subjects who have already experienced seizures or have epilepsy. Similarly, by increasing our knowledge about the specific changes that occur in $\mathrm{GABA}_{\mathrm{A}}$ receptor composition and pharmacology, it may be possible to design more selective and specific $\mathrm{GABA}_{\mathrm{A}}$ receptor agonists for the very young or epileptic brain that is refractory to the existing medications. At the anatomical and electrophysiological level, it might be feasible, one day, to design such specific, very targeted, and individualized therapies to enhance GABA inhibition and stop seizures. The biggest challenge will be however to predict the functional state of $\mathrm{GABA}_{\mathrm{A}}$ receptormediated inhibition at the target areas, so as to implement such rational therapies. Emerging evidence suggests that GABA-acting drugs, hormones, and different stressors are among the factors that can alter $\mathrm{GABA}_{\mathrm{A}}$ receptor signaling, rendering it almost a moving target [11, 30, 31, 192-196]. The need for biomarkers of $\mathrm{GABA}_{\mathrm{A}}$ function is therefore a priority.

\section{Conclusion}

The study of GABA in seizure generation and consequences has become a very fruitful field not only by generating intriguing results but also by producing challenging new questions. We have learned a number of mechanisms that compromise $\mathrm{GABA}_{\mathrm{A}}$ inhibition in the very young or epileptic brain, predisposing to seizures and the associated cognitive and neurodevelopmental deficits. We still need to better understand and, most importantly, predict which is the normal balance between excitation and inhibition with sufficient age, sex, cell type, and regional, context, and function-related specificity, so as to preserve normal brain function and development.

\section{Abbreviations}

$\mathrm{ADEFS}^{+}$: Autosomal dominant epilepsy with febrile seizures plus

ADJME: Autosomal dominant juvenile myoclonic epilepsy

ADNFLE: Autosomal dominant nocturnal frontal lobe epilepsy

ARX: Aristaless-related X-linked homeobox gene

BDNF: Brain-derived neurotrophic factor

CAE: Childhood absence epilepsy

GABA: Gamma aminobutyric acid

GABR: $\mathrm{GABA}_{\mathrm{A}}$ receptor

GAD: Glutamic acid decarboxylase

IGE: Idiopathic generalized epilepsy

IPSC: Inhibitory postsynaptic current

3KA-SE: 3 episodes of kainic acid SE at PN4,5,6

KCC: $\quad$ Potassium chloride cotransporter

LTP: Long-term potentiation

NKCC: Sodium potassium chloride cotransporter 
PN: $\quad$ Postnatal day

PTZ: Pentylenetetrazole

SCN1A: Sodium channel 1A

SMEI: Severe myoclonic epilepsy of infancy

SE: $\quad$ Status epilepticus

TLE: Temporal lobe epilepsy

UBE3A: Ubiquitin-protein ligase 3A.

\section{Acknowledgment}

The authors are grateful for the funding support of NIH (NINDS/NICHD Grants 62947; NINDS Grant 20253).

\section{References}

[1] A. T. Berg, S. F. Berkovic, M. J. Brodie et al., "Revised terminology and concepts for organization of seizures and epilepsies: report of the ILAE Commission on Classification and Terminology, 2005-2009," Epilepsia, vol. 51, no. 4, pp. 676-685, 2010.

[2] R. S. Fisher, W. van Emde Boas, W. Blume et al., "Epileptic seizures and epilepsy: definitions proposed by the International League Against Epilepsy (ILAE) and the International Bureau for Epilepsy (IBE)," Epilepsia, vol. 46, no. 4, pp. 470472, 2005.

[3] W. A. Hauser, J. F. Annegers, and L. T. Kurland, "Incidence of epilepsy and unprovoked seizures in Rochester, Minnesota: 1935-1984," Epilepsia, vol. 34, no. 3, pp. 453-468, 1993.

[4] I. A. W. Kotsopoulos, T. van Merode, F. G. H. Kessels, M. C. T. F. M. de Krom, and J. A. Knottnerus, "Systematic review and meta-analysis of incidence studies of epilepsy and unprovoked seizures," Epilepsia, vol. 43, no. 11, pp. 14021409, 2002.

[5] A. S. Galanopoulou, J. Vidaurre, and S. L. Moshé, "Under what circumstances can seizures produce hippocampal injury: evidence for age-specific effects," Developmental Neuroscience, vol. 24, no. 5, pp. 355-363, 2002.

[6] F. Pisani, C. Cerminara, C. Fusco, and L. Sisti, "Neonatal status epilepticus vs recurrent neonatal seizures: clinical findings and outcome," Neurology, vol. 69, no. 23, pp. 21772185, 2007.

[7] C. L. Padgett and P. A. Slesinger, "GABAB receptor coupling to G-proteins and ion channels," Advances in Pharmacology, vol. 57, pp. 123-147, 2010.

[8] K. M. McClellan, A. R. Calver, and S. A. Tobet, "GABAB receptors role in cell migration and positioning within the ventromedial nucleus of the hypothalamus," Neuroscience, vol. 151, no. 4, pp. 1119-1131, 2008.

[9] J. H. White, R. A. J. McIllhinney, A. Wise et al., "The GABA receptor interacts directly with the related transcription factors CREB2 and ATFx," Proceedings of the National Academy of Sciences of the United States of America, vol. 97, no. 25, pp. 13967-13972, 2000.

[10] R. B. Nehring, H. P. M. Horikawa, O. El Far et al., "The metabotropic $\mathrm{GABA}_{\mathrm{B}}$ receptor directly interacts with the activating transcription factor 4," Journal of Biological Chemistry, vol. 275, no. 45, pp. 35185-35191, 2000.

[11] A. S. Galanopoulou, " $G A B A_{A}$ receptors in normal development and seizures: friends or foes?" Current Neuropharmacology, vol. 6, no. 1, pp. 1-20, 2008.
[12] M. Farrant and K. Kaila, "The cellular, molecular and ionic basis of GABAA receptor signalling," Progress in Brain Research, vol. 160, pp. 59-87, 2007.

[13] R. W. Olsen and G. D. Li, “GABA $A_{A}$ receptors as molecular targets of general anesthetics: identification of binding sites provides clues to allosteric modulation," Canadian Journal of Anesthesia, pp. 1-10, 2010.

[14] P. Blaesse, M. S. Airaksinen, C. Rivera, and K. Kaila, "Cationchloride cotransporters and neuronal function," Neuron, vol. 61, no. 6, pp. 820-838, 2009.

[15] J. M. Russell, "Sodium-potassium-chloride cotransport," Physiological Reviews, vol. 80, no. 1, pp. 211-276, 2000.

[16] M. D. Plotkin, E. Y. Snyder, S. C. Hebert, and E. Delpire, "Expression of the Na-K-2Cl cotransporter is developmentally regulated in postnatal rat brains: a possible mechanism underlying GABA's excitatory role in immature brain," Journal of Neurobiology, vol. 33, no. 6, pp. 781-795, 1997.

[17] Y. Ben-Ari, E. Cherubini, R. Corradetti, and J. L. Gaiarsa, "Giant synaptic potentials in immature rat CA3 hippocampal neurones," Journal of Physiology, vol. 416, pp. 303-325, 1989.

[18] X. Leinekugel, I. Khalilov, H. McLean et al., "GABA is the principal fast-acting excitatory transmitter in the neonatal brain," Advances in Neurology, vol. 79, pp. 189-201, 1999.

[19] C. Rivera, J. Voipio, J. A. Payne et al., "The $\mathrm{K}^{+} / \mathrm{Cl}^{-}$cotransporter KCC2 renders GABA hyperpolarizing during neuronal maturation," Nature, vol. 397, no. 6716, pp. 251255, 1999.

[20] L. A. Jansen, L. D. Peugh, W. H. Roden, and J. G. Ojemann, "Impaired maturation of cortical $\mathrm{GABA}_{\mathrm{A}}$ receptor expression in pediatric epilepsy," Epilepsia, vol. 51, no. 8, pp. 1456-1467, 2010.

[21] V. I. Dzhala, D. M. Talos, D. A. Sdrulla et al., "NKCC1 transporter facilitates seizures in the developing brain," Nature Medicine, vol. 11, no. 11, pp. 1205-1213, 2005.

[22] C. Wang, C. Shimizu-Okabe, K. Watanabe et al., "Developmental changes in KCC1, KCC2, and NKCC1 mRNA expressions in the rat brain," Developmental Brain Research, vol. 139, no. 1, pp. 59-66, 2002.

[23] V. Stein, I. Hermans-Borgmeyer, T. J. Jentsch, and C. A. Hübner, "Expression of the KCl cotransporter KCC2 parallels neuronal maturation and the emergence of low intracellular chloride," Journal of Comparative Neurology, vol. 468, no. 1, pp. 57-64, 2004.

[24] K. Kaila, J. Voipio, P. Paalasmaa, M. Pasternack, and R. A. Deisz, "The role of bicarbonate in $\mathrm{GABA}_{\mathrm{A}}$ receptor-mediated IPSPs of rat neocortical neurones," Journal of Physiology, vol. 464, pp. 273-289, 1993.

[25] C. Rivera, J. Voipio, and K. Kaila, "Two developmental switches in GABAergic signalling: the $\mathrm{K}^{+}-\mathrm{Cl}^{-}$cotransporter KCC2 and carbonic anhydrase CAVII," Journal of Physiology, vol. 562, no. 1, pp. 27-36, 2005.

[26] E. Ruusuvuori, H. Li, K. Huttu et al., "Carbonic anhydrase isoform VII acts as a molecular switch in the development of synchronous gamma-frequency firing of hippocampal CA1 pyramidal cells," Journal of Neuroscience, vol. 24, no. 11, pp. 2699-2707, 2004.

[27] M. H. Scantlebury, A. S. Galanopoulou, L. Chudomelova, E. Raffo, D. Betancourth, and S. L. Moshé, "A model of symptomatic infantile spasms syndrome," Neurobiology of Disease, vol. 37, no. 3, pp. 604-612, 2010. 
[28] S. Vanhatalo, J. Matias Palva, S. Andersson, C. Rivera, J. Voipio, and K. Kaila, "Slow endogenous activity transients and developmental expression of $\mathrm{K}^{+}-\mathrm{Cl}^{-}$cotransporter 2 in the immature human cortex," European Journal of Neuroscience, vol. 22, no. 11, pp. 2799-2804, 2005.

[29] A. S. Galanopoulou, "Sexually dimorphic expression of KCC2 and GABA function," Epilepsy Research, vol. 80, no. 23, pp. 99-113, 2008.

[30] A. S. Galanopoulou, "Dissociated gender-specific effects of recurrent seizures on GABA signaling in CA1 pyramidal neurons: role of GABAA receptors," Journal of Neuroscience, vol. 28, no. 7, pp. 1557-1567, 2008.

[31] A. S. Galanopoulou, A. Kyrozis, O. I. Claudio, P. K. Stanton, and S. L. Moshé, "Sex-specific KCC2 expression and GABA receptor function in rat substantia nigra," Experimental Neurology, vol. 183, no. 2, pp. 628-637, 2003.

[32] J. L. Nuñez and M. M. McCarthy, "Evidence for an extended duration of GABA-mediated excitation in the developing male versus female hippocampus," Developmental Neurobiology, vol. 67, no. 14, pp. 1879-1890, 2007.

[33] Y. Ben-Ari, "Excitatory actions of GABA during development: the nature of the nurture," Nature Reviews Neuroscience, vol. 3, no. 9, pp. 728-739, 2002.

[34] M. A. Montenegro, M. M. Guerreiro, J. P. S. Caldas, M. V. L. Moura-Ribeiro, and C. A. M. Guerreiro, "Epileptic manifestations induced by midazolam in the neonatal period," Arquivos de Neuro-Psiquiatria, vol. 59, no. 2A, pp. 242-243, 2001.

[35] J. Connell, R. Oozeer, L. de Vries, L. M. S. Dubowitz, and V. Dubowitz, "Clinical and EEG response to anticonvulsants in neonatal seizures," Archives of Disease in Childhood, vol. 64, no. 4, pp. 459-464, 1989.

[36] D. Booth and D. J. Evans, "Anticonvulsants for neonates with seizures," Cochrane Database of Systematic Reviews, no. 4, Article ID CD004218, 2004.

[37] C. Chiron, O. Dulac, D. Beaumont, L. Palacios, N. Pajot, and J. Mumford, "Therapeutic trial of vigabatrin in refractory infantile spasms," Journal of Child Neurology, vol. 6, no. 2, pp. S52-S59, 1991.

[38] A. L. Lux, S. W. Edwards, E. Hancock et al., "The United Kingdom Infantile Spasms Study (UKISS) comparing hormone treatment with vigabatrin on developmental and epilepsy outcomes to age 14 months: a multicentre randomised trial," The Lancet Neurology, vol. 4, no. 11, pp. 712717, 2005.

[39] V. I. Dzhala, A. C. Brumback, and K. J. Staley, "Bumetanide enhances phenobarbital efficacy in a neonatal seizure model," Annals of Neurology, vol. 63, no. 2, pp. 222-235, 2008.

[40] K. Staley, "Enhancement of the excitatory actions of GABA by barbiturates and benzodiazepines," Neuroscience Letters, vol. 146, no. 1, pp. 105-107, 1992.

[41] J. M. Fritschy, J. Paysan, A. Enna, and H. Mohler, "Switch in the expression of rat $\mathrm{GABA}_{\mathrm{A}}$-receptor subtypes during postnatal development: an immunohistochemical study," Journal of Neuroscience, vol. 14, no. 9, pp. 5302-5324, 1994.

[42] O. Chudomel, H. Herman, K. Nair, S. L. Moshé, and A. S. Galanopoulou, "Age- and gender-related differences in GABAA receptor-mediated postsynaptic currents in GABAergic neurons of the substantia nigra reticulata in the rat," Neuroscience, vol. 163, no. 1, pp. 155-167, 2009.

[43] S. L. Moshé, E. F. Sperber, L. L. Brown, and A. Tempel, "Age-dependent changes in substantia nigra GABA-mediated seizure suppression," Epilepsy Research. Supplement, vol. 8, pp. 97-106, 1992.
[44] J. Velikova and S. L. Moshe, "Sexual dimorphism and developmental regulation of substantia nigra function," Annals of Neurology, vol. 50, no. 5, pp. 596-601, 2001.

[45] E. F. Sperber, J. Velísková, I. M. Germano, L. K. Friedman, and S. L. Moshé, "Age-dependent vulnerability to seizures," Advances in Neurology, vol. 79, pp. 161-169, 1999.

[46] A. Kyrozis, O. Chudomel, S. L. Moshé, and A. S. Galanopoulou, "Sex-dependent maturation of GABAA receptor-mediated synaptic events in rat substantia nigra reticulata," Neuroscience Letters, vol. 398, no. 1-2, pp. 1-5, 2006.

[47] P. Cossette, L. Liu, K. Brisebois et al., "Mutation of GABRA1 in an autosomal dominant form of juvenile myoclonic epilepsy," Nature Genetics, vol. 31, no. 2, pp. 184-189, 2002.

[48] L. Ding, H. J. Feng, R. L. Macdonald, E. J. Botzolakis, $\mathrm{N}$. $\mathrm{Hu}$, and $\mathrm{M}$. J. Gallagher, "GABA $\mathrm{A}_{\mathrm{A}}$ receptor $\alpha 1$ subunit mutation $\mathrm{A} 322 \mathrm{D}$ associated with autosomal dominant juvenile myoclonic epilepsy reduces the expression and alters the composition of wild type $\mathrm{GABA}_{\mathrm{A}}$ receptors," Journal of Biological Chemistry, vol. 285, no. 34, pp. 26390-26405, 2010.

[49] L. M. Dibbens, L. A. Harkin, M. Richards et al., "The role of neuronal $\mathrm{GABA}_{\mathrm{A}}$ receptor subunit mutations in idiopathic generalized epilepsies," Neuroscience Letters, vol. 453, no. 3, pp. 162-165, 2009.

[50] L. Urak, M. Feucht, N. Fathi, K. Hornik, and K. Fuchs, "A GABRB3 promoter haplotype associated with childhood absence epilepsy impairs transcriptional activity," Human Molecular Genetics, vol. 15, no. 16, pp. 2533-2541, 2006.

[51] M. Feucht, K. Fuchs, E. Pichlbauer et al., "Possible association between childhood absence epilepsy and the gene encoding GABRB3," Biological Psychiatry, vol. 46, no. 7, pp. 997-1002, 1999.

[52] M. Tanaka, R. W. Olsen, M. T. Medina et al., "Hyperglycosylation and reduced GABA currents of mutated GABRB3 polypeptide in remitting childhood absence epilepsy," American Journal of Human Genetics, vol. 82, no. 6, pp. 1249-1261, 2008.

[53] L. M. Dibbens, H. J. Feng, M. C. Richards et al., "GABRD encoding a protein for extra- or peri-synaptic GABAA receptors is susceptibility locus for generalized epilepsies," Human Molecular Genetics, vol. 13, no. 13, pp. 1315-1319, 2004.

[54] S. Baulac, G. Huberfeld, I. Gourfinkel-An et al., "First genetic evidence of $\mathrm{GABA}_{\mathrm{A}}$ receptor dysfunction in epilepsy: a mutation in the $\gamma 2$-subunit gene," Nature Genetics, vol. 28, no. 1, pp. 46-48, 2001.

[55] H. Sun, Y. Zhang, J. Liang et al., "SCN1A, SCN1B, and GABRG2 gene mutation analysis in Chinese families with generalized epilepsy with febrile seizures plus," Journal of Human Genetics, vol. 53, no. 8, pp. 769-774, 2008.

[56] L. A. Harkin, D. N. Bowser, L. M. Dibbens et al., "Truncation of the $\mathrm{GABA}_{\mathrm{A}}$-receptor $\gamma 2$ subunit in a family with generalized epilepsy with febrile seizures plus," American Journal of Human Genetics, vol. 70, no. 2, pp. 530-536, 2002.

[57] J. Q. Kang, W. Shen, and R. L. Macdonald, "The GABRG2 mutation, Q351X, associated with generalized epilepsy with febrile seizures plus, has both loss of function and dominantnegative suppression," Journal of Neuroscience, vol. 29, no. 9, pp. 2845-2856, 2009.

[58] S. Hirose, "A new paradigm of channelopathy in epilepsy syndromes: intracellular trafficking abnormality of channel molecules," Epilepsy Research, vol. 70, pp. S206-S217, 2006. 
[59] D. Audenaert, E. Schwartz, K. G. Claeys et al., "A novel GABRG2 mutation associated with febrile seizures," Neurology, vol. 67, no. 4, pp. 687-690, 2006.

[60] S. F. Kash, R. S. Johnson, L. H. Tecott et al., "Epilepsy in mice deficient in the $65-\mathrm{kDa}$ isoform of glutamic acid decarboxylase," Proceedings of the National Academy of Sciences of the United States of America, vol. 94, no. 25, pp. 14060-14065, 1997.

[61] H. Asada, Y. Kawamura, K. Maruyama et al., "Mice lacking the $65 \mathrm{kDa}$ isoform of glutamic acid decarboxylase (GAD65) maintain normal levels of GAD67 and GABA in their brains but are susceptible to seizures," Biochemical and Biophysical Research Communications, vol. 229, no. 3, pp. 891-895, 1996.

[62] M. Kato, "A new paradigm for West syndrome based on molecular and cell biology," Epilepsy Research, vol. 70, supplement 1, pp. S87-S95, 2006.

[63] M. Kato, S. Das, K. Petras et al., "Mutations of ARX are associated with striking pleiotropy and consistent genotypephenotype correlation," Human Mutation, vol. 23, no. 2, pp. 147-159, 2004.

[64] E. Marsh, C. Fulp, E. Gomez et al., "Targeted loss of Arx results in a developmental epilepsy mouse model and recapitulates the human phenotype in heterozygous females," Brain, vol. 132, no. 6, pp. 1563-1576, 2009.

[65] M. Kato, N. Koyama, M. Ohta, K. Miura, and K. Hayasaka, "Frameshift mutations of the ARX gene in familial Ohtahara syndrome," Epilepsia, vol. 51, no. 9, pp. 1679-1684, 2010.

[66] M. G. Price, J. W. Yoo, D. L. Burgess et al., "A triplet repeat expansion genetic mouse model of infantile spasms syndrome, $\operatorname{Ar} x^{(\mathrm{GCG}) 10+7}$, with interneuronopathy, spasms in infancy, persistent seizures, and adult cognitive and behavioral impairment," Journal of Neuroscience, vol. 29, no. 27, pp. 8752-8763, 2009.

[67] M. G. Frei, H. P. Zaveri, S. Arthurs et al., "Controversies in epilepsy: debates held during the Fourth International Workshop on Seizure Prediction," Epilepsy and Behavior, vol. 19, no. 1, pp. 4-16, 2010.

[68] D. G. Margineanu, "Epileptic hypersynchrony revisited," NeuroReport, vol. 21, no. 15, pp. 963-967, 2010.

[69] A. Klaassen, J. Glykys, J. Maguire, C. Labarca, I. Mody, and J. Boulter, "Seizures and enhanced cortical GABAergic inhibition in two mouse models of human autosomal dominant nocturnal frontal lobe epilepsy," Proceedings of the National Academy of Sciences of the United States of America, vol. 103, no. 50, pp. 19152-19157, 2006.

[70] E. O. Mann and I. Mody, "The multifaceted role of inhibition in epilepsy: seizure-genesis through excessive GABAergic inhibition in autosomal dominant nocturnal frontal lobe epilepsy," Current Opinion in Neurology, vol. 21, no. 2, pp. 155-160, 2008.

[71] L. Danober, C. Deransart, A. Depaulis, M. Vergnes, and C. Marescaux, "Pathophysiological mechanisms of genetic absence epilepsy in the rat," Progress in Neurobiology, vol. 55, no. 1, pp. 27-57, 1998.

[72] L. Cancedda, H. Fiumelli, K. Chen, and M. M. Poo, "Excitatory GABA action is essential for morphological maturation of cortical neurons in vivo," Journal of Neuroscience, vol. 27, no. 19, pp. 5224-5235, 2007.

[73] K. Nakanishi, J. Yamada, C. Takayama, A. Oohira, and A. Fukuda, "NKCC1 activity modulates formation of functional inhibitory synapses in cultured neocortical neurons," Synapse, vol. 61, no. 3, pp. 138-149, 2007.
[74] D. D. Wang and A. R. Kriegstein, "Blocking early GABA depolarization with bumetanide results in permanent alterations in cortical circuits and sensorimotor gating deficits," Cerebral Cortex, vol. 21, no. 3, pp. 574-587, 2011.

[75] S. Maljevic, K. Krampfl, J. Cobilanschi et al., "A mutation in the $\mathrm{GABA}_{\mathrm{A}}$ receptor $\alpha 1$-subunit is associated with absence epilepsy," Annals of Neurology, vol. 59, no. 6, pp. 983-987, 2006.

[76] J. Q. Kang, W. Shen, M. Lee, M. J. Gallagher, and R. L. Macdonald, "Slow degradation and aggregation in vitro of mutant GABAA receptor $\gamma 2(\mathrm{Q} 351 \mathrm{X})$ subunits associated with epilepsy," Journal of Neuroscience, vol. 30, no. 41, pp. 13895-13905, 2010.

[77] A. S. Galanopoulou, "Mutations affecting GABAergic signaling in seizures and epilepsy," Pflügers Archiv European Journal of Physiology, vol. 460, no. 2, pp. 505-523, 2010.

[78] R. L. Macdonald, J. Q. Kang, and M. J. Gallagher, "Mutations in GABAA receptor subunits associated with genetic epilepsies," Journal of Physiology, vol. 588, no. 11, pp. 1861-1869, 2010.

[79] C. Chiu, C. A. Reid, H. O. Tan et al., "Developmental impact of a familial GABAA receptor epilepsy mutation," Annals of Neurology, vol. 64, no. 3, pp. 284-293, 2008.

[80] D. L. Kaufman, C. R. Houser, and A. J. Tobin, "Two forms of the $\gamma$-aminobutyric acid synthetic enzyme glutamate decarboxylase have distinct intraneuronal distributions and cofactor interactions," Journal of Neurochemistry, vol. 56, no. 2, pp. 720-723, 1991.

[81] A. B. Walls, E. M. Eyjolfsson, O. B. Smeland et al., "Knockout of GAD65 has major impact on synaptic GABA synthesized from astrocyte-derived glutamine," Journal of Cerebral Blood Flow and Metabolism, 2010.

[82] A. B. Walls, L. H. Nilsen, E. M. Eyjolfsson et al., "GAD65 is essential for synthesis of GABA destined for tonic inhibition regulating epileptiform activity," Journal of Neurochemistry, vol. 115, no. 6, pp. 1398-1408, 2010.

[83] S. Kure, Y. Sakata, S. Miyahayashi et al., "Mutation and polymorphic marker analyses of $65 \mathrm{~K}$ - and $67 \mathrm{~K}$-glutamate decarboxylase genes in two families with pyridoxine-dependent epilepsy," Journal of Human Genetics, vol. 43, no. 2, pp. 128131, 1998.

[84] S. M. Gospe Jr., "Pyridoxine-dependent seizures: new genetic and biochemical clues to help with diagnosis and treatment," Current Opinion in Neurology, vol. 19, no. 2, pp. 148-153, 2006.

[85] S. M. Gospe Jr., K. L. Olin, and C. L. Keen, "Reduced GABA synthesis in pyridoxine-dependent seizures," The Lancet, vol. 343, no. 8906, pp. 1133-1134, 1994.

[86] H. Asada, Y. Kawamura, K. Maruyama et al., "Cleft palate and decreased brain $\gamma$-aminobutyric acid in mice lacking the 67-kDa isoform of glutamic acid decarboxylase," Proceedings of the National Academy of Sciences of the United States of America, vol. 94, no. 12, pp. 6496-6499, 1997.

[87] F. Ji, N. Kanbara, and K. Obata, "GABA and histogenesis in fetal and neonatal mouse brain lacking both the isoforms of glutamic acid decarboxylase," Neuroscience Research, vol. 33, no. 3, pp. 187-194, 1999.

[88] P. Kwan, G. J. Sills, K. Kelly, E. Butler, and M. J. Brodie, "Glutamic acid decarboxylase autoantibodies in controlled and uncontrolled epilepsy: a pilot study," Epilepsy Research, vol. 42, no. 2-3, pp. 191-195, 2000.

[89] T. Yoshimoto, M. Doi, N. Fukai et al., “Type 1 diabetes mellitus and drug-resistant epilepsy: presence of high titer 
of antiglutamic acid decarboxylase autoantibodies in serum and cerebrospinal fluid," Internal Medicine, vol. 44, no. 11, pp. 1174-1177, 2005.

[90] D. A. Pearce, M. Atkinson, and D. A. Tagle, "Glutamic acid decarboxylase autoimmunity in Batten disease and other disorders," Neurology, vol. 63, no. 11, pp. 2001-2005, 2004.

[91] K. McKnight, Y. Jiang, Y. Hart et al., "Serum antibodies in epilepsy and seizure-associated disorders," Neurology, vol. 65, no. 11, pp. 1730-1736, 2005.

[92] M. B. Rust, S. L. Alper, Y. Rudhard et al., "Disruption of erythroid $\mathrm{K}-\mathrm{Cl}$ cotransporters alters erythrocyte volume and partially rescues erythrocyte dehydration in SAD mice," Journal of Clinical Investigation, vol. 117, no. 6, pp. 1708-1717, 2007.

[93] C. A. Hübner, V. Stein, I. Hermans-Borgmeyer, T. Meyer, K. Ballanyi, and T. J. Jentsch, "Disruption of KCC2 reveals an essential role of $\mathrm{K}-\mathrm{Cl}$ cotransport already in early synaptic inhibition," Neuron, vol. 30, no. 2, pp. 515-524, 2001.

[94] N. S. Woo, J. Lu, R. England et al., "Hyperexcitability and epilepsy associated with disruption of the mouse neuronalspecific K-Cl cotransporter gene," Hippocampus, vol. 12, no. 2, pp. 258-268, 2002.

[95] J. Tornberg, V. Voikar, H. Savilahti, H. Rauvala, and M. S. Airaksinen, "Behavioural phenotypes of hypomorphic KCC2-deficient mice," European Journal of Neuroscience, vol. 21, no. 5, pp. 1327-1337, 2005.

[96] L. Zhu, N. Polley, G. C. Mathews, and E. Delpire, "NKCC1 and KCC2 prevent hyperexcitability in the mouse hippocampus," Epilepsy Research, vol. 79, no. 2-3, pp. 201-212, 2008.

[97] N. Dupré, H. C. Howard, J. Mathieu et al., "Hereditary motor and sensory neuropathy with agenesis of the corpus callosum," Annals of Neurology, vol. 54, no. 1, pp. 9-18, 2003.

[98] J. Mathieu, F. Bedard, C. Prevost, and P. Langevin, "Hereditary motor and sensory neuropathy with or without agenesis of the corpus callosum. Radiological and clinical study of 64 cases," Canadian Journal of Neurological Sciences, vol. 17, no. 2, pp. 103-108, 1990.

[99] H. C. Howard, D. B. Mount, D. Rochefort et al., "The $\mathrm{K}-\mathrm{Cl}$ cotransporter $\mathrm{KCC} 3$ is mutant in a severe peripheral neuropathy associated with agenesis of the corpus callosum," Nature Genetics, vol. 32, no. 3, pp. 384-392, 2002.

[100] T. Boettger, M. B. Rust, H. Maier et al., "Loss of K-Cl co-transporter KCC3 causes deafness, neurodegeneration and reduced seizure threshold," The EMBO Journal, vol. 22, no. 20, pp. 5422-5434, 2003.

[101] T. Boettger, C. A. Hübner, H. Maier, M. B. Rust, F. X. Beck, and T. J. Jentsch, "Deafness and renal tubular acidosis in mice lacking the K-Cl co-transporter Kcc4," Nature, vol. 416, no. 6883, pp. 874-878, 2002.

[102] M. J. Dixon, J. Gazzard, S. S. Chaudhry, N. Sampson, B. A. Schulte, and K. P. Steel, "Mutation of the Na-K-Cl cotransporter gene Slc12a2 results in deafness in mice," Human Molecular Genetics, vol. 8, no. 8, pp. 1579-1584, 1999.

[103] A. J. Pace, V. J. Madden, O. W. Henson, B. H. Koller, and M. M. Henson, "Ultrastructure of the inner ear of NKCC1deficient mice," Hearing Research, vol. 156, no. 1-2, pp. 17-30, 2001.

[104] E. Delpire, J. Lu, R. England, C. Dull, and T. Thorne, "Deafness and imbalance associated with inactivation of the secretory Na-K-2Cl co-transporter," Nature Genetics, vol. 22, no. 2, pp. 192-195, 1999.

[105] D. B. Simon, F. E. Karet, J. M. Hamdan, A. Di Pietro, S. A. Sanjad, and R. P. Lifton, "Bartter's syndrome, hypokalaemic alkalosis with hypercalciuria, is caused by mutations in the Na-K-2CI cotransporter NKCC2," Nature Genetics, vol. 13, no. 2, pp. 183-188, 1996.

[106] P. Uvarov, A. Ludwig, M. Markkanen et al., "A novel Nterminal isoform of the neuron-specific $\mathrm{K}-\mathrm{Cl}$ cotransporter KCC2," Journal of Biological Chemistry, vol. 282, no. 42, pp. 30570-30576, 2007.

[107] K. J. Staley and I. Mody, "Shunting of excitatory input to dentate gyrus granule cells by a depolarizing $\mathrm{GABA}_{\mathrm{A}}$ receptor-mediated postsynaptic conductance," Journal of Neurophysiology, vol. 68, no. 1, pp. 197-212, 1992.

[108] H. Li, S. Khirug, C. Cai et al., "KCC2 interacts with the dendritic cytoskeleton to promote spine development," Neuron, vol. 56, no. 6, pp. 1019-1033, 2007.

[109] T. Viitanen, E. Ruusuvuori, K. Kaila, and J. Voipio, "The $\mathrm{K}^{+}-\mathrm{Cl}^{-}$cotransporter KCC2 promotes GABAergic excitation in the mature rat hippocampus," Journal of Physiology, vol. 588, no. 9, pp. 1527-1540, 2010.

[110] D. D. Wang and A. R. Kriegstein, "GABA regulates excitatory synapse formation in the neocortex via NMDA receptor activation," Journal of Neuroscience, vol. 28, no. 21, pp. 5547-5558, 2008.

[111] A. T. Berg, S. N. Smith, D. Frobish et al., "Special education needs of children with newly diagnosed epilepsy," Developmental Medicine and Child Neurology, vol. 47, no. 11, pp. 749-753, 2005.

[112] K. Kitamura, M. Yanazawa, N. Sugiyama et al., "Mutation of ARX causes abnormal development of forebrain and testes in mice and X-linked lissencephaly with abnormal genitalia in humans," Nature Genetics, vol. 32, no. 3, pp. 359-369, 2002.

[113] G. Friocourt, K. Poirier, S. Rakić, J. G. Parnavelas, and J. Chelly, "The role of ARX in cortical development," European Journal of Neuroscience, vol. 23, no. 4, pp. 869-876, 2006.

[114] P. Strømme, M. E. Mangelsdorf, I. E. Scheffer, and J. Gécz, "Infantile spasms, dystonia, and other X-linked phenotypes caused by mutations in Aristaless related homeobox gene, ARX," Brain and Development, vol. 24, no. 5, pp. 266-268, 2002.

[115] G. Turner, M. Partington, B. Kerr, M. Mangelsdorf, and J. Gecz, "Variable expression of mental retardation, autism, seizures, and dystonic hand movements in two families with an identical ARX gene mutation," American Journal of Medical Genetics, vol. 112, no. 4, pp. 405-411, 2002.

[116] M. W. Partington, G. Turner, J. Boyle, and J. Gécz, “Three new families with X-linked mental retardation caused by the 428-451dup(24bp) mutation in ARX," Clinical Genetics, vol. 66, no. 1, pp. 39-45, 2004.

[117] G. Friocourt and J. G. Parnavelas, "Mutations in ARX result in several defects involving GABAergic neurons," Frontiers in Cellular Neuroscience, vol. 4, p. 4, 2010.

[118] B. A. Minassian, T. M. DeLorey, R. W. Olsen et al., "Angelman syndrome: correlations between epilepsy phenotypes and genotypes," Annals of Neurology, vol. 43, no. 4, pp. 485-493, 1998.

[119] G. E. Homanics, T. M. DeLorey, L. L. Firestone et al., "Mice devoid of $\gamma$-aminobutyrate type A receptor $\beta 3$ subunit have epilepsy, cleft palate, and hypersensitive behavior," Proceedings of the National Academy of Sciences of the United States of America, vol. 94, no. 8, pp. 4143-4148, 1997.

[120] S. F. Berkovic, L. Harkin, J. M. McMahon et al., "De-novo mutations of the sodium channel gene SCN1A in alleged vaccine encephalopathy: a retrospective study," The Lancet Neurology, vol. 5, no. 6, pp. 488-492, 2006. 
[121] L. A. Harkin, J. M. McMahon, X. Iona et al., "The spectrum of SCN1A-related infantile epileptic encephalopathies," Brain, vol. 130, no. 3, pp. 843-852, 2007.

[122] S. E. Heron, I. E. Scheffer, X. Iona et al., "De novo SCN1A mutations in Dravet syndrome and related epileptic encephalopathies are largely of paternal origin," Journal of Medical Genetics, vol. 47, no. 2, pp. 137-141, 2010.

[123] R. H. Wallace, B. L. Hodgson, B. E. Grinton et al., "Sodium channel $\alpha 1$-subunit mutations in severe myoclonic epilepsy of infancy and infantile spasms," Neurology, vol. 61, no. 6, pp. 765-769, 2003.

[124] M. S. Martin, K. Dutt, L. A. Papale et al., "Altered function of the SCN1A voltage-gated sodium channel leads to $\gamma$-aminobutyric acid-ergic (GABAergic) interneuron abnor-malities," Journal of Biological Chemistry, vol. 285, no. 13, pp. 98239834, 2010.

[125] H. Prüss, J. Dalmau, L. Harms et al., "Retrospective analysis of NMDA receptor antibodies in encephalitis of unknown origin," Neurology, vol. 75, no. 19, pp. 1735-1739, 2010.

[126] T. Iizuka and F. Sakai, "Anti-NMDA receptor encephalitisclinical manifestations and pathophysiology," Brain and Nerve, vol. 60, no. 9, pp. 1047-1060, 2008.

[127] E. Aronica, K. Boer, S. Redeker et al., "Differential expression patterns of chloride transporters, $\mathrm{Na}^{+}-\mathrm{K}^{+}-2 \mathrm{Cl}^{-}-$ cotransporter and $\mathrm{K}^{+}-\mathrm{Cl}^{-}$-cotransporter, in epilepsyassociated malformations of cortical development," Neuroscience, vol. 145, no. 1, pp. 185-196, 2007.

[128] C. Cepeda, V. M. André, N. Wu et al., "Immature neurons and GABA networks may contribute to epileptogenesis in pediatric cortical dysplasia," Epilepsia, vol. 48, supplement 5, pp. 79-85, 2007.

[129] C. Shimizu-Okabe, A. Okabe, W. Kilb, K. Sato, H. J. Luhmann, and A. Fukuda, "Changes in the expression of cation- $\mathrm{Cl}^{-}$cotransporters, NKCC1 and $\mathrm{KCC} 2$, during cortical malformation induced by neonatal freeze-lesion," Neuroscience Research, vol. 59, no. 3, pp. 288-295, 2007.

[130] O. Peters, C. Redecker, G. Hagemann, C. Bruehl, H. J. Luhmann, and O. W. Witte, "Impaired synaptic plasticity in the surround of perinatally aquired dysplasia in rat cerebral cortex," Cerebral Cortex, vol. 14, no. 10, pp. 1081-1087, 2004.

[131] J. J. Hablitz and R. A. DeFazio, "Altered receptor subunit expression in rat neocortical malformations," Epilepsia, vol. 41, no. 6, pp. S82-S85, 2000.

[132] E. A. Benardete and A. R. Kriegstein, "Increased excitability and decreased sensitivity to GABA in an animal model of dysplastic cortex," Epilepsia, vol. 43, no. 9, pp. 970-982, 2002.

[133] J. Nabekura, T. Ueno, A. Okabe et al., "Reduction of KCC2 expression and GABAA receptor-mediated excitation after in vivo axonal injury," Journal of Neuroscience, vol. 22, no. 11, pp. 4412-4417, 2002.

[134] H. Toyoda, K. Ohno, J. Yamada et al., "Induction of NMDA and GABAA receptor-mediated $\mathrm{Ca}^{2+}$ oscillations with KCC2 mRNA downregulation in injured facial motoneurons," Journal of Neurophysiology, vol. 89, no. 3, pp. 1353-1362, 2003.

[135] A. Shulga, J. Thomas-Crusells, T. Sigl et al., "Posttraumatic $\mathrm{GABA}_{\mathrm{A}}$-mediated $\left[\mathrm{Ca}^{2+}\right]_{\mathrm{i}}$ increase is essential for the induction of brain-derived neurotrophic factor-dependent survival of mature central neurons," Journal of Neuroscience, vol. 28, no. 27, pp. 6996-7005, 2008.

[136] X. Jin, J. R. Huguenard, and D. A. Prince, "Impaired $\mathrm{Cl}^{-}$ extrusion in layer $\mathrm{V}$ pyramidal neurons of chronically injured epileptogenic neocortex," Journal of Neurophysiology, vol. 93, no. 4, pp. 2117-2126, 2005.
[137] X. Jin, J. R. Huguenard, and D. A. Prince, "Reorganization of inhibitory synaptic circuits in rodent chronically injured epileptogenic neocortex," Cerebral Cortex, vol. 21, no. 5, pp. 1094-1104, 2011.

[138] P. G. Ochalski, W. Fellows-Mayle, L. B. Hsieh et al., "Flumazenil administration attenuates cognitive impairment in immature rats after controlled cortical impact," Journal of Neurotrauma, vol. 27, no. 3, pp. 647-651, 2010.

[139] H. P. Goodkin, S. Joshi, Z. Mtchedlishvili, J. Brar, and J. Kapur, "Subunit-specific trafficking of $\mathrm{GABA}_{\mathrm{A}}$ receptors during status epilepticus," Journal of Neuroscience, vol. 28, no. 10 , pp. 2527-2538, 2008.

[140] D. E. Naylor, H. Liu, and C. G. Wasterlain, "Trafficking of $\mathrm{GABA}_{\mathrm{A}}$ receptors, loss of inhibition, and a mechanism for pharmacoresistance in status epilepticus," Journal of Neuroscience, vol. 25, no. 34, pp. 7724-7733, 2005.

[141] E. Isaeva, D. Isaev, R. Khazipov, and G. L. Holmes, "Selective impairment of GABAergic synaptic transmission in the flurothyl model of neonatal seizures," European Journal of Neuroscience, vol. 23, no. 6, pp. 1559-1566, 2006.

[142] E. Isaeva, D. Isaev, R. Khazipov, and G. L. Holmes, "Longterm suppression of GABAergic activity by neonatal seizures in rat somatosensory cortex," Epilepsy Research, vol. 87, no. 2-3, pp. 286-289, 2009.

[143] H. Ni, Y. W. Jiang, T. Bo, J. M. Wang, and X. R. Wu, “c-Fos, $\mathrm{N}$-methyl-D-aspartate receptor 2C, GABA-A- $\alpha 1$ immonoreactivity, seizure latency and neuronal injury following single or recurrent neonatal seizures in hippocampus of Wistar rat," Neuroscience Letters, vol. 380, no. 1-2, pp. 149-154, 2005.

[144] H. B. Laurén, F. R. Lopez-Picon, E. R. Korpi, and I. E. Holopainen, "Kainic acid-induced status epilepticus alters GABAA receptor subunit mRNA and protein expression in the developing rat hippocampus," Journal of Neurochemistry, vol. 94, no. 5, pp. 1384-1394, 2005.

[145] G. Zhang, Y. H. Raol, F. C. Hsu, D. A. Coulter, and A. R. Brooks-Kayal, "Effects of status epilepticus on hippocampal GABAA receptors are age-dependent," Neuroscience, vol. 125, no. 2, pp. 299-303, 2004.

[146] Y. H. Raol, G. Zhang, I. V. Lund, B. E. Porter, M. A. Maronski,

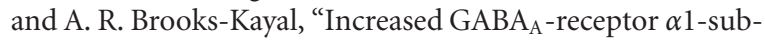
unit expression in hippocampal dentate gyrus after early-life status epilepticus," Epilepsia, vol. 47, no. 10, pp. 1665-1673, 2006.

[147] N. S. Abend, A. M. Gutierrez-Colina, and D. J. Dlugos, "Medical treatment of pediatric status epilepticus," Seminars in Pediatric Neurology, vol. 17, no. 3, pp. 169-175, 2010.

[148] P. Shearer and J. Riviello, "Generalized convulsive status epilepticus in adults and children: treatment guidelines and protocols," Emergency Medicine Clinics of North America, vol. 29, no. 1, pp. 51-64, 2011.

[149] H. D. Lux and U. Heinemann, "Ionic changes during experimentally induced seizure activity," Electroencephalography and Clinical Neurophysiology. Supplement, no. 34, pp. 289-297, 1978.

[150] V. I. Dzhala, K. V. Kuchibhotla, J. C. Glykys et al., "Progressive NKCC1-dependent neuronal chloride accumulation during neonatal seizures," Journal of Neuroscience, vol. 30, no. 35, pp. 11745-11761, 2010.

[151] C. Rivera, J. Voipio, J. Thomas-Crusells et al., "Mechanism of activity-dependent downregulation of the neuron-specific K-Cl cotransporter KCC2," Journal of Neuroscience, vol. 24, no. 19, pp. 4683-4691, 2004. 
[152] U. Sayin, S. Osting, J. Hagen, P. Rutecki, and T. Sutula, "Spontaneous seizures and loss of axo-axonic and axo-somatic inhibition induced by repeated brief seizures in kindled rats," Journal of Neuroscience, vol. 23, no. 7, pp. 2759-2768, 2003.

[153] A. Obenaus, M. Esclapez, and C. R. Houser, "Loss of glutamate decarboxylase mRNA-containing neurons in the rat dentate gyrus following pilocarpine-induced seizures," Journal of Neuroscience, vol. 13, no. 10, pp. 4470-4485, 1993.

[154] L. Wang, Y. H. Liu, Y. G. Huang, and L. W. Chen, "Timecourse of neuronal death in the mouse pilocarpine model of chronic epilepsy using Fluoro-Jade C staining," Brain Research, vol. 1241, pp. 157-167, 2008.

[155] J. P. Leite, T. L. Babb, J. K. Pretorius, P. A. Kuhlman, K. M. Yeoman, and G. W. Mathern, "Neuron loss, mossy fiber sprouting, and interictal spikes after intrahippocampal kainate in developing rats," Epilepsy Research, vol. 26, no. 1, pp. 219-231, 1996.

[156] R. S. Sloviter, C. A. Zappone, B. D. Harvey, A. V. Bumanglag, R. A. Bender, and M. Frotscher, "Dormant basket cell" hypothesis revisited: relative vulnerabilities of dentate gyrus mossy cells and inhibitory interneurons after hippocampal status epilepticus in the rat," Journal of Comparative Neurology, vol. 459, no. 1, pp. 44-76, 2003.

[157] J. M. Fritschy, T. Kiener, V. Bouilleret, and F. Loup, "GABAergic neurons and $\mathrm{GABA}_{\mathrm{A}}$-receptors in temporal lobe epilepsy," Neurochemistry International, vol. 34, no. 5, pp. 435-445, 1999.

[158] K. Z. Haas, E. F. Sperber, L. A. Opanashuk, P. K. Stanton, and S. L. Moshé, "Resistance of immature hippocampus to morphologic and physiologic alterations following status epilepticus or kindling," Hippocampus, vol. 11, no. 6, pp. 615-625, 2001.

[159] C. E. Stafstrom, J. L. Thompson, and G. L. Holmes, "Kainic acid seizures in the developing brain: status epilepticus and spontaneous recurrent seizures," Developmental Brain Research, vol. 65, no. 2, pp. 227-236, 1992.

[160] L. Nitecka, E. Tremblay, and G. Charton, "Maturation of kainic acid seizure-brain damage syndrome in the rat. II. Histopathological sequelae," Neuroscience, vol. 13, no. 4, pp. 1073-1094, 1984.

[161] D. J. Laurie, W. Wisden, and P. H. Seeburg, "The distribution of thirteen $\mathrm{GABA}_{\mathrm{A}}$ receptor subunit mRNAs in the rat brain. III. Embryonic and postnatal development," Journal of Neuroscience, vol. 12, no. 11, pp. 4151-4172, 1992.

[162] Y. H. Raol, I. V. Lund, S. Bandyopadhyay et al., "Enhancing $\mathrm{GABA}_{\mathrm{A}}$ receptor $\alpha 1$ subunit levels in hippocampal dentate gyrus inhibits epilepsy development in an animal model of temporal lobe epilepsy," Journal of Neuroscience, vol. 26, no. 44, pp. 11342-11346, 2006.

[163] I. Cohen, V. Navarro, S. Clemenceau, M. Baulac, and R. Miles, "On the origin of interictal activity in human temporal lobe epilepsy in vitro," Science, vol. 298, no. 5597, pp. 1418-1421, 2002.

[164] G. Huberfeld, L. Wittner, S. Clemenceau et al., "Perturbed chloride homeostasis and GABAergic signaling in human temporal lobe epilepsy," Journal of Neuroscience, vol. 27, no. 37, pp. 9866-9873, 2007.

[165] W. G. Reiss and K. S. Oles, "Acetazolamide in the treatment of seizures," Annals of Pharmacotherapy, vol. 30, no. 5, pp. 514-518, 1996.

[166] X. Li, J. Zhou, Z. Chen, S. Chen, F. Zhu, and L. Zhou, "Longterm expressional changes of $\mathrm{Na}^{+}-\mathrm{K}^{+}-\mathrm{Cl}^{-}$co-transporter
1 (NKCC1) and $\mathrm{K}^{+}-\mathrm{Cl}^{-}$co-transporter 2 (KCC2) in CA1 region of hippocampus following lithium-pilocarpine induced status epilepticus (PISE)," Brain Research, vol. 1221, pp. 141-146, 2008.

[167] A. Muñoz, P. Méndez, J. Defelipe, and F. J. AlvarezLeefmans, "Cation-chloride cotransporters and GABA-ergic innervation in the human epileptic hippocampus," Epilepsia, vol. 48, no. 4, pp. 663-673, 2007.

[168] E. Palma, M. Amici, F. Sobrero et al., "Anomalous levels of $\mathrm{Cl}^{-}$transporters in the hippocampal subiculum from temporal lobe epilepsy patients make GABA excitatory," Proceedings of the National Academy of Sciences of the United States of America, vol. 103, no. 22, pp. 8465-8468, 2006.

[169] A. Sen, L. Martinian, M. Nikolic, M. C. Walker, M. Thom, and S. M. Sisodiya, "Increased NKCC1 expression in refractory human epilepsy," Epilepsy Research, vol. 74, no. 2-3, pp. 220-227, 2007.

[170] M. Munakata, M. Watanabe, T. Otsuki et al., "Altered distribution of KCC2 in cortical dysplasia in patients with intractable epilepsy," Epilepsia, vol. 48, no. 4, pp. 837-844, 2007.

[171] S. Khirug, F. Ahmad, M. Puskarjov, R. Afzalov, K. Kaila, and P. Blaesse, "A single seizure episode leads to rapid functional activation of KCC2 in the neonatal rat hippocampus," Journal of Neuroscience, vol. 30, no. 36, pp. 12028-12035, 2010.

[172] F. Aguado, M. A. Carmona, E. Pozas et al., "BDNF regulates spontaneous correlated activity at early developmental stages by increasing synaptogenesis and expression of the $\mathrm{K}^{+} / \mathrm{Cl}^{-}$ co-transporter KCC2," Development, vol. 130, no. 7, pp. 1267-1280, 2003.

[173] C. Rivera, H. Li, J. Thomas-Crusells et al., "BDNF-induced TrkB activation down-regulates the $\mathrm{K}^{+}-\mathrm{Cl}^{-}$cotransporter $\mathrm{KCC} 2$ and impairs neuronal $\mathrm{Cl}^{-}$extrusion," Journal of Cell Biology, vol. 159, no. 5, pp. 747-752, 2002.

[174] W. Wang, N. Gong, and T. -L. Xu, "Downregulation of KCC2 following LTP contributes to EPSP-spike potentiation in rat hippocampus," Biochemical and Biophysical Research Communications, vol. 343, no. 4, pp. 1209-1215, 2006.

[175] W. Wang, H. Wang, N. Gong, and T. L. Xu, "Changes of $\mathrm{K}^{+}-\mathrm{Cl}^{-}$cotransporter 2 (KCC2) and circuit activity in pro-pofol-induced impairment of long-term potentiation in rat hippocampal slices," Brain Research Bulletin, vol. 70, no. 4-6, pp. 444-449, 2006.

[176] C. J. McBain and J. A. Kauer, "Presynaptic plasticity: targeted control of inhibitory networks," Current Opinion in Neurobiology, vol. 19, no. 3, pp. 254-262, 2009.

[177] H. T. Chao, H. Chen, R. C. Samaco et al., "Dysfunction in GABA signalling mediates autism-like stereotypies and Rett syndrome phenotypes," Nature, vol. 468, no. 7321, pp. 263-269, 2010.

[178] G. Di Cristo, "Development of cortical GABAergic circuits and its implications for neurodevelopmental disorders," Clinical Genetics, vol. 72, no. 1, pp. 1-8, 2007.

[179] A. L. Collins, D. Ma, P. L. Whitehead et al., "Investigation of autism and GABA receptor subunit genes in multiple ethnic groups," Neurogenetics, vol. 7, no. 3, pp. 167-174, 2006.

[180] I. A. J. van Kooten, P. R. Hof, H. van Engeland, H. W. M. Steinbusch, P. H. Patterson, and C. Schmitz, "Autism: neuropathology, alterations of the GABAergic system, and animal models," International Review of Neurobiology, vol. 71, pp. 1-26, 2005.

[181] C. D'Hulst, I. Heulens, J. R. Brouwer et al., "Expression of the GABAergic system in animal models for fragile $\mathrm{X}$ syndrome 
and fragile X associated tremor/ataxia syndrome (FXTAS)," Brain Research, vol. 1253, pp. 176-183, 2009.

[182] T. M. DeLorey and R. W. Olsen, "GABA and epileptogenesis: comparing gabrb3 gene-deficient mice with Angelman syndrome in man," Epilepsy Research, vol. 36, no. 2-3, pp. 123-132, 1999.

[183] E. Lemonnier and Y. Ben-Ari, "The diuretic bumetanide decreases autistic behaviour in five infants treated during 3 months with no side effects," Acta Paediatrica, vol. 99, no. 12, pp. 1885-1888, 2010.

[184] I. Khalilov, G. L. Holmes, and Y. Ben-Ari, "In vitro formation of a secondary epileptogenic mirror focus by interhippocampal propagation of seizures," Nature Neuroscience, vol. 6, no. 10, pp. 1079-1085, 2003.

[185] A. S. Galanopoulou, "Developmental patterns in the regulation of chloride homeostasis and $\mathrm{GABA}_{\mathrm{A}}$ receptor signaling by seizures," Epilepsia, vol. 48, no. 5, pp. 14-18, 2007.

[186] R. Nardou, Y. Ben-Ari, and I. Khalilov, "Bumetanide, an NKCC1 antagonist, does not prevent formation of epileptogenic focus but blocks epileptic focus seizures in immature rat hippocampus," Journal of Neurophysiology, vol. 101, no. 6, pp. 2878-2888, 2009.

[187] P. Mares, "Age-and dose-specific anticonvulsant action of bumetanide in immature rats," Physiological Research, vol. 58, no. 6, pp. 927-930, 2009.

[188] C. Brandt, M. Nozadze, N. Heuchert, M. Rattka, and W. Löscher, "Disease-modifying effects of phenobarbital and the NKCC1 inhibitor bumetanide in the pilocarpine model of temporal lobe epilepsy," Journal of Neuroscience, vol. 30, no. 25, pp. 8602-8612, 2010.

[189] A. Mazarati, D. Shin, and R. Sankar, "Bumetanide inhibits rapid kindling in neonatal rats," Epilepsia, vol. 50, no. 9, pp. 2117-2122, 2009.

[190] K. T. Kahle, S. M. Barnett, K. C. Sassower, and K. J. Staley, "Decreased seizure activity in a human neonate treated with bumetanide, an inhibitor of the $\mathrm{Na}^{+}-\mathrm{K}^{+}-2 \mathrm{Cl}^{-}$cotransporter NKCC1," Journal of Child Neurology, vol. 24, no. 5, pp. 572-576, 2009.

[191] W. Kilb, A. Sinning, and H. J. Luhmann, "Model-specific effects of bumetanide on epileptiform activity in the in-vitro intact hippocampus of the newborn mouse," Neuropharmacology, vol. 53, no. 4, pp. 524-533, 2007.

[192] A. S. Galanopoulou and S. L. Moshé, "Role of sex hormones in the sexually dimorphic expression of KCC2 in rat substantia nigra," Experimental Neurology, vol. 184, no. 2, pp. 1003-1009, 2003.

[193] F. C. Hsu, G. J. Zhang, Y. S. H. Raol, R. J. Valentino, D. A. Coulter, and A. R. Brooks-Kayal, "Repeated neonatal handling with maternal separation permanently alters hippocampal GABAA receptors and behavioral stress responses," Proceedings of the National Academy of Sciences of the United States of America, vol. 100, no. 21, pp. 12213-12218, 2003.

[194] K. Ganguly, A. F. Schinder, S. T. Wong, and M. M. Poo, "GABA itself promotes the developmental switch of neuronal GABAergic responses from excitation to inhibition," Cell, vol. 105, no. 4, pp. 521-532, 2001.

[195] M. Ceanga, A. Spataru, and A. M. Zagrean, "Oxytocin is neuroprotective against oxygen-glucose deprivation and reoxygenation in immature hippocampal cultures," Neuroscience Letters, vol. 477, no. 1, pp. 15-18, 2010.

[196] R. Khazipov, R. Tyzio, and Y. Ben-Ari, "Effects of oxytocin on GABA signalling in the foetal brain during delivery," Progress in Brain Research, vol. 170, pp. 243-257, 2008. 

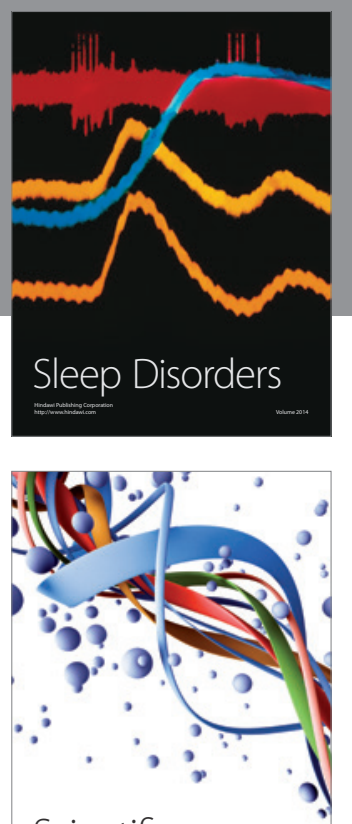

Scientifica
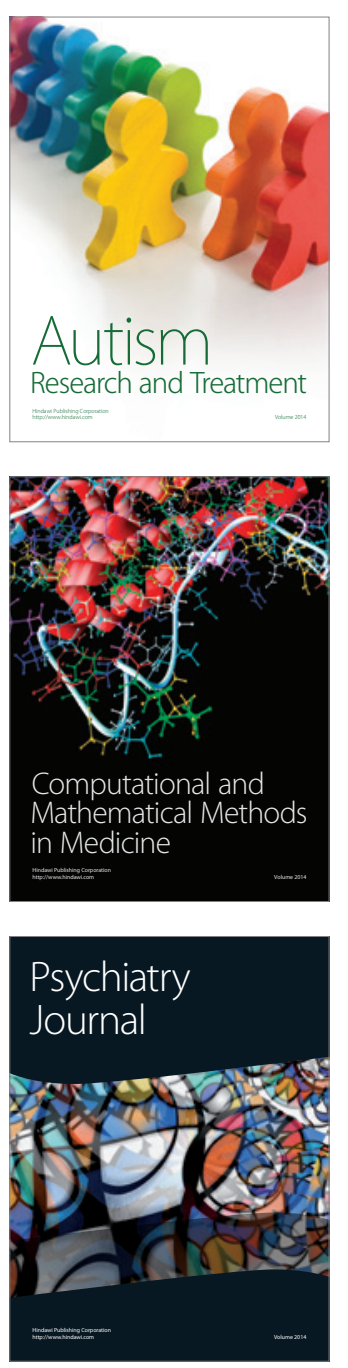
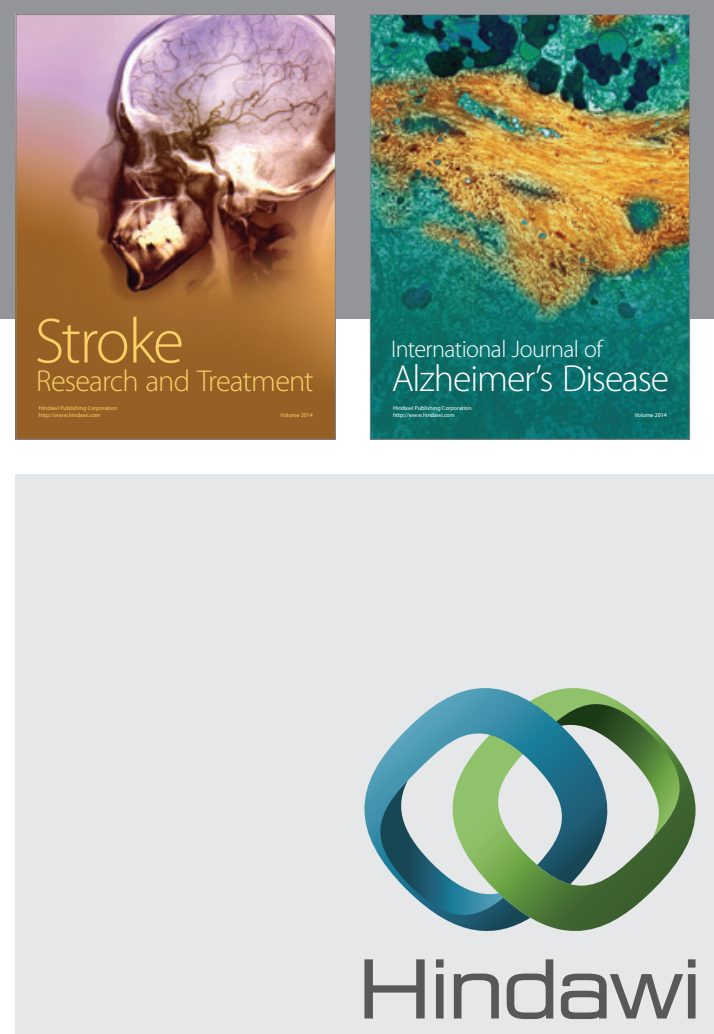

Submit your manuscripts at

http://www.hindawi.com
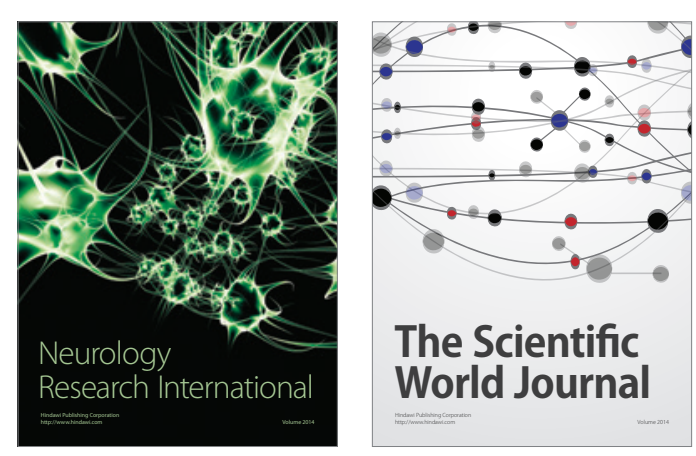

The Scientific World Journal

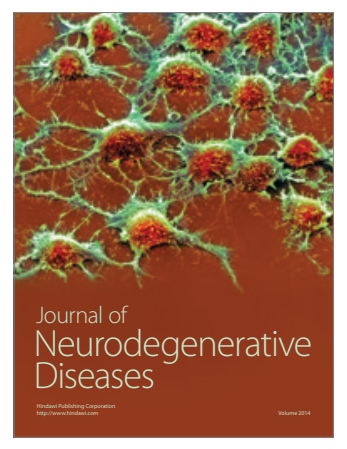

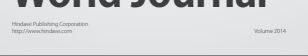

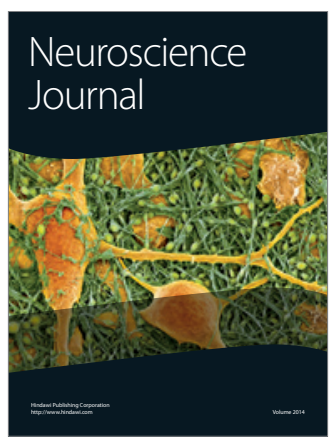

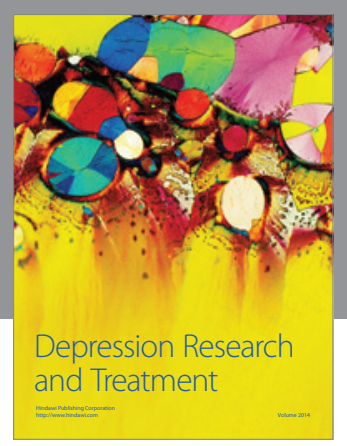
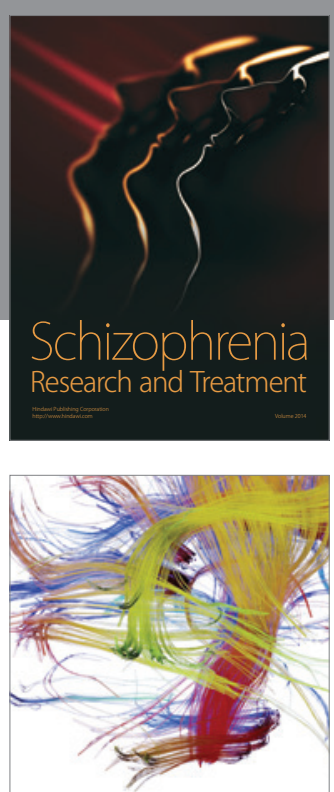

Brain Science

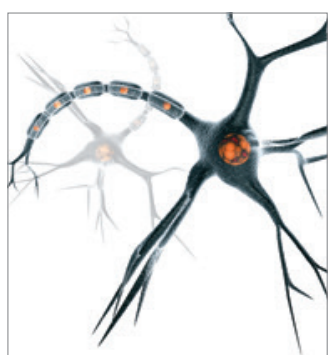

Neural Plasticity
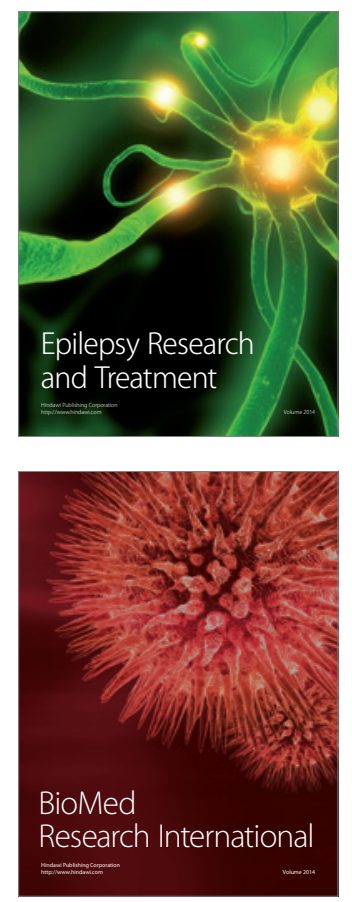

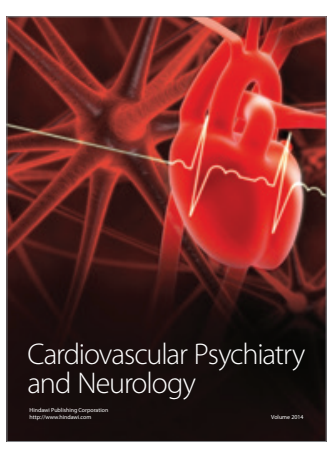

Parkinson's

Disease
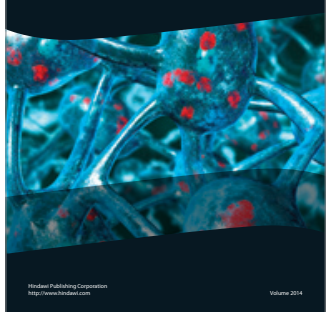